\title{
A model-data comparison of the Holocene global sea surface temperature evolution
}

\author{
G. Lohmann ${ }^{1}$, M. Pfeiffer ${ }^{1}$, T. Laepple ${ }^{1}$, G. Leduc ${ }^{2}$, and J.-H. Kim ${ }^{3}$ \\ ${ }^{1}$ Alfred Wegener Institute, Helmholtz Centre for Polar and Marine Research, Bussestrasse 24, 27570 Bremerhaven, Germany \\ ${ }^{2}$ Kiel University, Institute of Earth Sciences, Ludewig-Meyn-Str. 10, 24118 Kiel, Germany \\ ${ }^{3}$ Royal Netherlands Institute for Sea Research, P.O. Box 59, 1790 AB Den Burg, Texel, the Netherlands
}

Correspondence to: G. Lohmann (gerrit.lohmann@awi.de)

Received: 22 March 2012 - Published in Clim. Past Discuss.: 29 March 2012

Revised: 11 June 2013 - Accepted: 23 June 2013 - Published: 6 August 2013

\begin{abstract}
We compare the ocean temperature evolution of the Holocene as simulated by climate models and reconstructed from marine temperature proxies. We use transient simulations from a coupled atmosphere-ocean general circulation model, as well as an ensemble of time slice simulations from the Paleoclimate Modelling Intercomparison Project. The general pattern of sea surface temperature (SST) in the models shows a high-latitude cooling and a low-latitude warming. The proxy dataset comprises a global compilation of marine alkenone- and $\mathrm{Mg} / \mathrm{Ca}$-derived SST estimates. Independently of the choice of the climate model, we observe significant mismatches between modelled and estimated SST amplitudes in the trends for the last $6000 \mathrm{yr}$. Alkenone-based SST records show a similar pattern as the simulated annual mean SSTs, but the simulated SST trends underestimate the alkenone-based SST trends by a factor of two to five. For $\mathrm{Mg} / \mathrm{Ca}$, no significant relationship between model simulations and proxy reconstructions can be detected. We test if such discrepancies can be caused by too simplistic interpretations of the proxy data. We explore whether consideration of different growing seasons and depth habitats of the planktonic organisms used for temperature reconstruction could lead to a better agreement of model results with proxy data on a regional scale. The extent to which temporal shifts in growing season or vertical shifts in depth habitat can reduce model-data misfits is determined. We find that invoking shifts in the living season and habitat depth can remove some of the model-data discrepancies in SST trends. Regardless whether such adjustments in the environmental parameters during the Holocene are realistic, they indicate that when modelled temperature trends are set up to allow drastic shifts
\end{abstract}

in the ecological behaviour of planktonic organisms, they do not capture the full range of reconstructed SST trends. Results indicate that modelled and reconstructed temperature trends are to a large degree only qualitatively comparable, thus providing a challenge for the interpretation of proxy data as well as the model sensitivity to orbital forcing.

\section{Introduction}

A serious problem of future environmental conditions is how increasing human industrialisation with growing emissions of greenhouse gases will induce a significant impact on the earth's climate. Information beyond the instrumental record covering the last $150 \mathrm{yr}$ can be obtained mainly from two strategies: on the one hand by deriving from proxies which record past climate and environmental conditions, and on the other hand by simulating climate, using comprehensive models of the climate system under appropriate external forcing. Numerical climate models are clearly unequalled in their ability to simulate a broad suite of phenomena in the climate system (Jansen et al., 2007), but their reliability on longer timescales requires additional evaluation. Only climate records derived from palaeoenvironmental proxies enable the test of these models because they provide records of climate variations that have actually occurred in the past. However, well-known uncertainties in the proxyderived palaeoclimate records exist, e.g. age control, signal formation, or calibration issues (Bradley, 1999). 
Performing model-data comparisons can help reduce uncertainties in both model simulations and reconstruction of past climate change, and thus provide a test for climate projections as derived from climate models (e.g. Schmidt, 2010). In this perspective, the climate evolution from the mid-Holocene to the pre-industrial (PI) conditions is an ideal test bed for models, as the main forcing for temperature trends (insolation) for this period is known from astronomical theory (Berger, 1978), and a relatively large number of high-resolution and well-dated proxy records are available (e.g. Leduc et al., 2010a). Such records constrain the climate response to changes in external forcing (e.g. Hansen, 2007). However, uncertainties remain regarding important variables, such as temperature responses, the amplitude and feedbacks on long timescales and on large spatial scales (Köhler et al., 2010; Rohling et al., 2012).

There have been several studies focused on model-data comparisons of the mid-Holocene climate evolution devoted to identifying and explaining model-data mismatches. For example, Masson et al. (1999) and Guiot et al. (1999) compare mid-Holocene pollen- and lake-status-based reconstructions of European climate to an ensemble of atmosphere general circulation model (AGCM) climate simulations. They find little coherency among different models in the simulations of European climate change during the Holocene, and conclude that the North Atlantic sea surface temperature (SST) evolution that was not considered in those atmosphereonly simulations may be crucial to adequately simulate European climate evolution. A more recent analysis of Brewer et al. (2007) compare the output of 25 atmosphere-ocean general circulation model (AOGCM) simulations of the midHolocene period with a set of palaeoclimate reconstructions based on over 400 fossil pollen sequences, distributed across the European continent. They find better agreement between model results and proxy data, but the models still faced difficulties in capturing the magnitude of climate change. Sundqvist et al. (2010) provide an overview of northern highlatitude temperature change, and find that most proxies were terrestrial, and summer biased. By taking simple arithmetic averages over the available data, the reconstructions indicate that the northern high latitudes were $2^{\circ} \mathrm{C}$ warmer in annual mean temperature during the mid-Holocene compared to the recent pre-industrial. This compilation (Sundqvist et al., 2010) and modelling studies (Lorenz and Lohmann, 2004; Zhang et al., 2010) indicate that the strongest warming in the Arctic Ocean realm is in autumn, which is closely related to a delayed sea-ice response to summer insolation. A recent compilation of land proxy data and models (Braconnot et al., 2012) shows mean annual temperature anomalies of $2-5 \mathrm{~K}$ during the mid-Holocene over large parts of northern and middle Europe, parts of northern Asia, as well as southern Africa. In the Mediterranean and the subtropical regions, the data shows a cooling of $1-2 \mathrm{~K}$, as seen from pollen and plant macrofossil data (Bartlein et al., 2011).
Previous data compilation based on SST reconstructions during the mid-to-late Holocene mainly focus on large-scale pattern in the North Atlantic realm (Marchal et al., 2002; Rimbu et al., 2003), Pacific-Atlantic teleconnections (Kim et al., 2004), linkages between high and low latitudes (Rimbu et al., 2004) and global trends (Lorenz et al., 2006; Leduc et al., 2010a). The set of Holocene SST records that we use here is derived from alkenones and $\mathrm{Mg} / \mathrm{Ca}$, two proxies that are commonly used and thus largely applied over the last two decades (e.g. Brassell et al., 1986; Prahl and Wakeham, 1987; Prahl et al., 1988; Rosell-Melé et al., 1995; Nürnberg et al., 1996; Schneider et al., 1996; Bard et al., 1997; Conte et al., 1998; Herbert et al., 1998; Müller et al., 1998; Rosenthal et al., 2004; Greaves et al., 2008). Alkenones are synthesized by a small number of Haptophyceae phytoplankton of which the coccolithophorids Emiliania huxleyi and Gephyrocapsa oceanica are the two most common sources in the present oceans and modern sediments. Here, we consider mainly two parameters that might influence estimations of Holocene SST trends: changes in seasonal changes in coccolithophorid production (e.g. Rosell-Melé et al., 1995; Sikes et al., 1997; Ternois et al., 1997; Davis and Brewer, 2009), and changes in their depth habitat (e.g. Ternois et al., 1997; Bentaleb et al., 1999; Ohkouchi et al., 1999). Alkenones record a temperature signal that reflects the surrounding water temperature during the algae's lifetime. This recorded signal can be influenced by species-dependent ecological preferences, hence, the reconstructed temperature signal may depend on the seasonality and depth habitat of the alkenoneproducing organisms (e.g. Müller et al., 1998; Baumann et al., 2000; Andruleit et al., 2003). In a similar way, planktonic foraminifera, which produce tests from which $\mathrm{Mg} / \mathrm{Ca}$ SST estimates are derived, thrive over wide ranges of seasons and water depths (e.g. Fairbanks et al., 1982; Deuser and Ross, 1989; Mohtadi et al., 2009; Regenberg et al., 2009; Fallet et al., 2010).

Here, we specifically address this issue by presenting a comparison of simulated and reconstructed ocean temperatures for the mid-to-late Holocene ( 6 to $0 \mathrm{kyr} \mathrm{BP}-$ before present). We compare results from an ensemble of transient simulations of the Holocene, performed with the ECHO-G model (Lorenz and Lohmann, 2004), to marine alkenone- and $\mathrm{Mg} / \mathrm{Ca}$-based temperature reconstructions. Previous studies indicated an agreement in the tendency between marine proxy reconstructions and model simulations of the temperature evolution, but a mismatch with respect to the amplitude of the temperature trends (Lorenz et al., 2006; Schneider et al., 2010). Therefore, it has been speculated that taking into account proxy specificities associated with the ecological behaviour of planktonic organisms from which SST are derived can remove parts of the observed mismatches. For instance, changes in surface water stratification and in seasonality of the planktonic organisms' living season could affect the proxy reconstructions. This may establish a diagnostic of why model-data mismatch is observed. 
Table 1. List of alkenone and $\mathrm{Mg} / \mathrm{Ca}$ records used in the paper. The data is available through http://doi.pangaea.de/10.1594/PANGAEA. 737370?offset=0\#dslist, and the metadata for alkenone (http://doi.pangaea.de/10.1594/PANGAEA.737301) and Mg/Ca (http://doi.pangaea. de/10.1594/PANGAEA.736946) records is also available.

\begin{tabular}{|c|c|c|c|c|c|c|}
\hline Core name & $\begin{array}{l}\text { Latitude } \\
{ }^{\circ} \mathrm{N}>0\end{array}$ & $\begin{array}{r}\text { Longitude } \\
{ }^{\circ} \mathrm{E}>0\end{array}$ & $\begin{array}{l}\text { Water } \\
\text { depth } \\
(\mathrm{m})\end{array}$ & $\begin{array}{r}\text { Coretop } \\
\text { SST } \\
\left({ }^{\circ} \mathrm{C}\right)\end{array}$ & $\begin{array}{r}6 \mathrm{kyr} \mathrm{BP} \\
\mathrm{SST} \\
\left({ }^{\circ} \mathrm{C}\right)\end{array}$ & Reference \\
\hline \multicolumn{7}{|c|}{ Alkenone-based SST reconstruction } \\
\hline M23258-2 & 74.995 & 13.97 & 1768 & 4.3 & 7.0 & $\begin{array}{l}\text { Marchal et al. (2002); } \\
\text { Sarnthein et al. (2003) }\end{array}$ \\
\hline MD95-2011 & 66.9667 & 7.633 & 1048 & 11.2 & 12.4 & Calvo et al. (2002) \\
\hline MD95-2015 & 58.762 & -25.958 & 2630 & 11.4 & 11.6 & Marchal et al. (2002) \\
\hline IOW225514 & 57.838 & 8.704 & 420 & 10.9 & 13.2 & Emeis et al. (2003) \\
\hline JT96-0909PC & 48.9117 & -126.89 & 920 & 10.1 & 10.2 & Kienast and McKay (2001) \\
\hline ODP1019C & 41.682 & -124.93 & 980 & 11.5 & 10.5 & Barron et al. (2003) \\
\hline M44-KL71 & 40.842 & 27.763 & 566 & 16.7 & 18.3 & Sperling et al. (2003) \\
\hline M40-4-SL78/78MUC8 & 37.036 & 13.19 & 470 & 17.2 & 18.9 & $\begin{array}{l}\text { Emeis and Dawson (2003); } \\
\text { Emeis and Schulz (unpublished) }\end{array}$ \\
\hline MD95-2043 & 36.1433 & -2.62167 & 1841 & 18.4 & 19.0 & Cacho et al. (1999) \\
\hline BS79-38 & 38.412 & 13.577 & 1489 & 16.9 & 16.1 & Cacho et al. (2001) \\
\hline BS79-33 & 38.262 & 14.03 & 1282 & 16.5 & 20.1 & Cacho et al. (2001) \\
\hline RL11 & 36.746 & 17.7175 & 3376 & 19.1 & 23.0 & Emeis et al. (2000) \\
\hline SSDP-102 & 34.9531 & 128.881 & 40 & 22.1 & 21.8 & Kim et al. (2004) \\
\hline ODP1017E & 34.535 & -121.107 & 955 & 15.3 & 15.1 & $\begin{array}{l}\text { Kennett et al. (2000); } \\
\text { Ostertag-Henning and Stax (2000) }\end{array}$ \\
\hline ST.14 & 32.668 & 138.455 & 3252 & 22.3 & 22.5 & Sawada and Handa (1998) \\
\hline GeoB5844-2 & 27.7135 & 34.6817 & 963 & 26.8 & 26.3 & Arz et al. (2003) \\
\hline SO90-93KL & 23.583 & 64.217 & 1802 & 27.4 & 27.5 & $\begin{array}{l}\text { Schulz et al. (2002); } \\
\text { Emeis (unpublished) }\end{array}$ \\
\hline ODP108-658C & 20.75 & -18.5833 & 2262.9 & 20.4 & 21.2 & $\begin{array}{l}\text { Zhao et al. (1995); } \\
\text { deMenocal et al. (2000) }\end{array}$ \\
\hline $17940-2$ & 20.1167 & 117.383 & 1727 & 26.8 & 26.6 & $\begin{array}{l}\text { Pelejero et al. (1999a); } \\
\text { Wang et al. (1999) }\end{array}$ \\
\hline $74 \mathrm{KL}$ & 14.321 & 57.347 & 3212 & 27.3 & 27.2 & Kim et al. (2004) \\
\hline M35003-4 & 12.0833 & -61.25 & 1299 & 28.2 & 27.9 & Rühlemann et al. (1999) \\
\hline TY93-905 & 11.0667 & 51.95 & 1567 & 25.7 & 25.2 & Kim et al. (2004) \\
\hline ODP165-1002C & 10.7122 & -65.1697 & 893 & 24.8 & 25.8 & $\begin{array}{l}\text { Herbert and Schuffert (2000); } \\
\text { Peterson et al. (2000) }\end{array}$ \\
\hline MD77194 & 10.4667 & 75.2333 & 1222 & 27.5 & 27.2 & Sonzogni et al. (1997) \\
\hline ODP175-1078C & -11.92 & 13.4 & 426 & 24.9 & 24.4 & Kim et al. (2003) \\
\hline GeoB1023-5 & -17.158 & 11.008 & 1978 & 20.8 & 22.1 & Kim et al. (2002) \\
\hline GeoB3313-1 & -41000 & -74.45 & 852 & 14.9 & 15.7 & Lamy et al. (2002) \\
\hline MD85674 & 3.183 & 50.433 & 4875 & 26.8 & 27.1 & Bard et al. (1997) \\
\hline GeoB 3129-1 & -4.613 & -36.637 & 830 & 27.9 & 28.1 & Kim et al. (2002) \\
\hline OCE326-GGC30 & 43.882 & -62.8 & 250 & 8.6 & 13.0 & Sachs (2007) \\
\hline OCE326-GGC26 & 43.483 & -54.867 & 3975 & 8.8 & 11.9 & Sachs (2007) \\
\hline KNR176-JPC32 & 4.847 & -77.963 & 2200 & 27.0 & 26.0 & Pahnke et al. (2007) \\
\hline MD02-2529 & 8.206 & -84.122 & 1619 & 28.9 & 27.6 & Leduc et al. (2007) \\
\hline ODP202-1233 & -41.008 & -74.45 & 838 & 14.0 & 14.9 & $\begin{array}{l}\text { Lamy et al. }(2004,2007) \text {; } \\
\text { Kaiser et al. (2005) }\end{array}$ \\
\hline GeoB4905-4 & 2.5 & 9.39 & 1328 & 27.0 & 25.1 & Weldeab et al. (2007a) \\
\hline GeoB6518-1 & -5.588 & 11.222 & 962 & 25.0 & 24.5 & Schefuss et al. (2005) \\
\hline MD03-2611 & -36.733 & 136.55 & 2420 & 17.9 & 19.6 & Calvo et al. (2007) \\
\hline MD01-2412 & 44.527 & 145.042 & 1225 & 12.3 & 11.9 & Harada et al. (2006) \\
\hline SO136-GC11 & -43.44 & 167.851 & 1556 & 14.7 & 15.9 & Barrows et al. (2008) \\
\hline V19-27 & -0.467 & -82.667 & 1373 & 26.5 & 25.2 & Koutavas and Sachs (2008) \\
\hline V19-30 & -3.383 & -83.517 & 3091 & 22.6 & 22.5 & Koutavas and Sachs (2008) \\
\hline GeoB7926-2 & 20.217 & -18.45 & 2500 & 20.4 & 21.2 & Romero et al. (2008) \\
\hline
\end{tabular}


Table 1. Continued.

\begin{tabular}{|c|c|c|c|c|c|c|}
\hline Core name & $\begin{array}{l}\text { Latitude } \\
{ }^{\circ} \mathrm{N}>0\end{array}$ & $\begin{array}{r}\text { Longitude } \\
{ }^{\circ} \mathrm{E}>0\end{array}$ & $\begin{array}{r}\text { Water } \\
\text { depth } \\
(\mathrm{m})\end{array}$ & $\begin{array}{r}\text { Coretop } \\
\text { SST } \\
\left({ }^{\circ} \mathrm{C}\right)\end{array}$ & $\begin{array}{r}6 \text { kyr BP } \\
\text { SST } \\
\left({ }^{\circ} \mathrm{C}\right)\end{array}$ & Reference \\
\hline \multicolumn{7}{|c|}{ Alkenone-based SST reconstruction } \\
\hline MD95-2042 & 37.799 & -10.166 & 3146 & 17.9 & 18.6 & Pailler and Bard (2002) \\
\hline MD01-2443 & 37.881 & -10.176 & 2925 & 17.3 & 18.0 & Martrat et al. (2007) \\
\hline JR51-GC35 & 66.999 & -17.961 & 420 & 7.1 & 6.9 & Bendle and Rosell-Mélé (2007) \\
\hline ODP161-977 & 36.032 & -1.955 & 1984 & 18.1 & 18.7 & Martrat et al. (2004) \\
\hline SO139-74KL & -6.543 & 103.833 & 1690 & 28.2 & 27.5 & Lückge et al. (2009) \\
\hline MD97-2151 & 8.729 & 109.869 & 1598 & 27.6 & 27.4 & Zhao et al. (2006) \\
\hline GeoB6007 & 30.85 & -10.2683 & 583 & 19.0 & 20.1 & Kim et al. (2007) \\
\hline PC17 & 21.358 & -158.19 & 503 & 25.6 & 25.5 & Lee et al. (2001) \\
\hline $\mathrm{PC} 2$ & 50.395 & 148.323 & 1258 & 8 & 7.7 & Seki et al. (2004) \\
\hline D13882 & 38.634 & -9.454 & 88 & 16.1 & 18.4 & Rodrigues et al. (2009) \\
\hline \multicolumn{7}{|c|}{$\mathrm{Mg} / \mathrm{Ca}-\mathrm{based} \mathrm{SST}$ reconstruction } \\
\hline MD03-2707 & 2.502 & 9.395 & 1295 & 25.5 & 26.9 & Weldeab et al. (2007b) \\
\hline GeoB4905-4 & 2.5 & 9.39 & 1328 & 26.2 & 26.7 & Weldeab et al. (2007a) \\
\hline GeoB3129/3911 & -4.613 & -36.637 & 830 & 27.1 & 27.2 & Weldeab et al. (2006) \\
\hline PL07-39PC & 10.7 & -65.942 & 790 & 26.7 & 26.4 & Lea et al. (2003) \\
\hline MD98-2181 & 6.3 & 125.83 & 2114 & 29.1 & 29.6 & Stott et al. (2004) \\
\hline MD98-2176 & -5.003 & 133.445 & 2382 & 28.7 & 29.3 & Stott et al. (2004) \\
\hline MD98-2170 & -10.592 & 125.388 & 832 & 29.4 & 29.7 & Stott et al. (2004) \\
\hline ODP202-1242/ME0005A-43JC & 7.856 & -83.608 & 1366 & 26.6 & 26.5 & Benway et al. (2006) \\
\hline ODP175-1084B & -25.514 & 13.278 & 1992 & 13.3 & 13.7 & Farmer et al. (2005) \\
\hline MD98-2162 & -4.689 & 117.903 & 1855 & 29.2 & 29.4 & Visser et al. (2003) \\
\hline ODP162-984 & 61000 & -25000 & 1648 & 7.6 & 8.5 & Came et al. (2007) \\
\hline A7 & 27.82 & 126.98 & 1264 & 26.6 & 26 & Sun et al. (2005) \\
\hline ODP202-1240 & 0.0218 & -86.446 & 2921 & 24.9 & 25.6 & Pena et al. (2008) \\
\hline MD99-2155 & 57.433 & -27.9 & 2620 & 11.9 & 10.2 & Farmer et al. (2008) \\
\hline MD02-2575 & 29.02 & -87.118 & 847 & 25.2 & 26.6 & Nürnberg et al. (2008) \\
\hline MD98-2165 & -9.649 & 118.338 & 2100 & 28.4 & 26.7 & Levi et al. (2007) \\
\hline MD01-2378 & -13.082 & 121.788 & 1783 & 28 & 28 & Xu et al. (2008) \\
\hline RAPID-12-1K & 62.09 & -17.82 & 1938 & 10.8 & 9.9 & Thornalley et al. (2009) \\
\hline MD01-2390 & 6.635 & 113.409 & 1545 & 27.6 & 28.3 & Steinke et al. (2008) \\
\hline
\end{tabular}

Here, we use our extended GHOST database (Leduc et al., 2010a), which comprises marine SST proxy records based on alkenones and $\mathrm{Mg} / \mathrm{Ca}$ (Table 1). We compare these data to ensemble simulations from a transient experiment as well as to a selection of climate model simulations for the midHolocene period. We then systematically explore whether the model-data mismatches could be reduced by invoking changes in seasonality or water depth structure within the limit of estimated ecological requirements. By quantifying marine sites where model-data mismatch may potentially be caused by a misinterpretation of the proxy record and by quantifying the potential influence of seasonality and habitat depth on the alkenone- and $\mathrm{Mg} / \mathrm{Ca}$-derived temperature, we evaluate possible reasons for the misfit of simulated Holocene SST trends with the proxies.

\section{Data and methods}

The marine alkenone-based temperature reconstructions are from the GHOST database (Kim and Schneider, 2004). We use an updated version of this database (Leduc et al., 2010a), which comprises marine proxy records for SST based on alkenones and $\mathrm{Mg} / \mathrm{Ca}$. The temperature reconstructions used here cover the mid-Holocene ( $6 \mathrm{kyr} \mathrm{BP})$ to the last millennium ( 0 to $1 \mathrm{kyr} B \mathrm{P}$, depending on the record), and consist of 52 alkenone-based SSTs (Figs. 1-3) and $19 \mathrm{Mg} / \mathrm{Ca}$-based SST records (Fig. 4). These are unevenly distributed over the world ocean and are mainly located in the North Atlantic Ocean and in coastal areas (Fig. 5). We only consider records that have at least 10 incorporated values. As our main interest is the pattern of SST evolution, we determine the linear temperature trends between 6 and $0 \mathrm{kyr}$ BP at every core location. These temperature trends show the spatial pattern of 

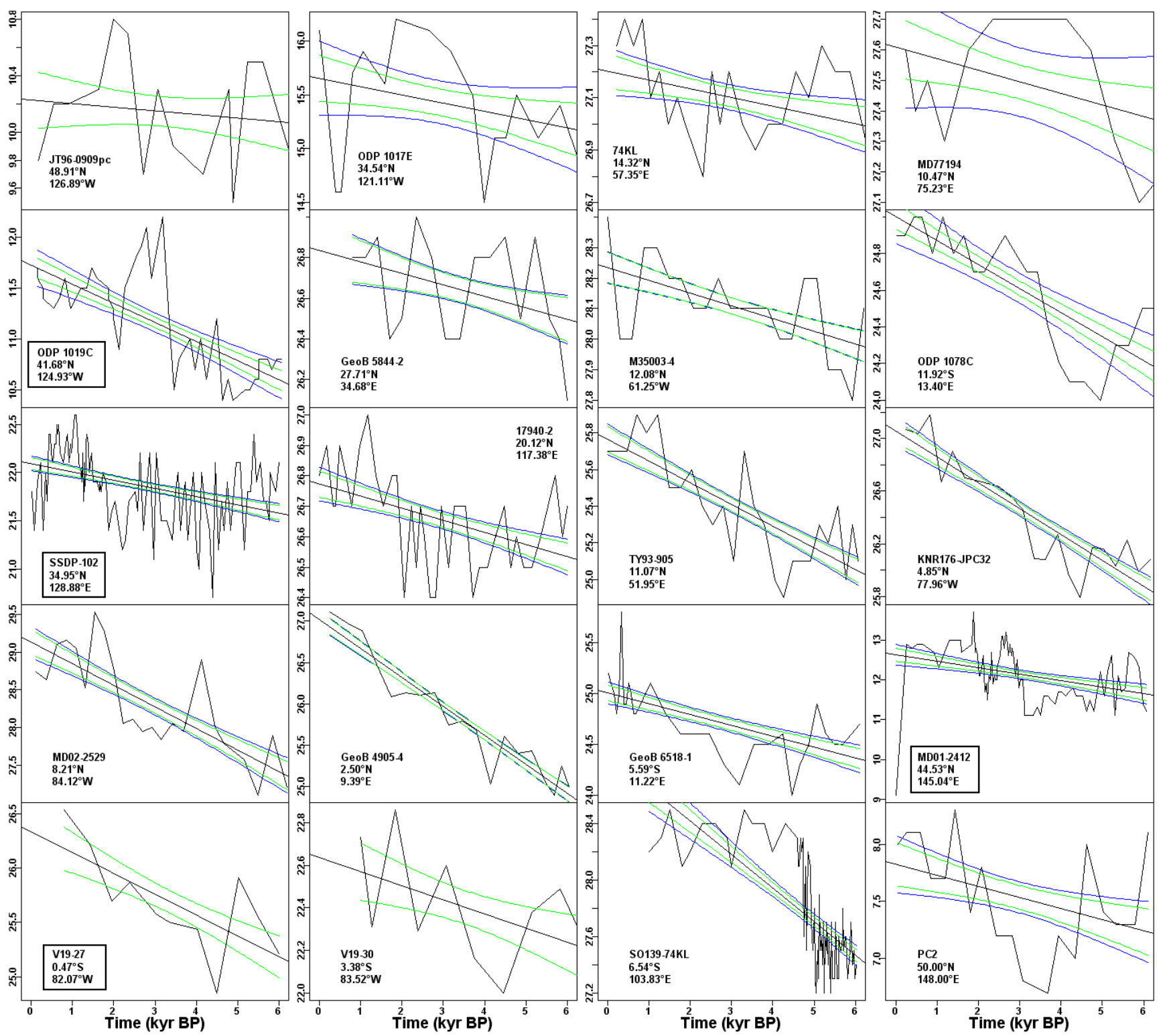

Fig. 1. Alkenone time series with positive linear trends and their standard errors. The blue curved lines represent the standard error that accounts for serial correlation, the green ones represent those not accounting for serial correlation. Name and position are included in the panels and in Table 1. The inserts provide information about the core location. Boxed inserts indicate cores which fail the residual test for randomness of the proxy linear regressions' residuals as described in Sect. 3.2.

temperature evolution since the mid-Holocene, as recorded by the marine temperature proxies. We evaluate the ocean model component of ECHO-G in simulating the seasonal cycle in SST for the core locations (Figs. S1-S4, Supplement).

Simulated temperatures are based on the ensemble mean of two transient experiments spanning 7 to $0 \mathrm{kyr} B P$, using the ECHO-G model (Lorenz and Lohmann, 2004). The model is described in Legutke and Voss (1999). It consists of the atmosphere model ECHAM4 (Roeckner et al., 1996) and the ocean general circulation model HOPE including a dynamical-thermodynamical model for sea ice (Wolff et al.,
1997). Only the orbital forcing has been applied in this experiment, and other parameters (e.g. $\mathrm{CO}_{2}$ ) have been set to pre-industrial (PI) values. Calculation of the orbital parameters follows the orbital solution of Berger (1978) and is accelerated by a factor of ten (Lorenz and Lohmann, 2004). The same model has been applied for the Eemian and glacial inception (Felis et al., 2004; Lohmann and Lorenz, 2007).

The ocean model grid consists of 120 unequally spaced grid cells in latitudinal direction, and 128 equally spaced grid cells in longitudinal direction; the equatorial latitudes between $\pm 10^{\circ}$ latitude have a resolution of $0.5^{\circ}$ in order to 

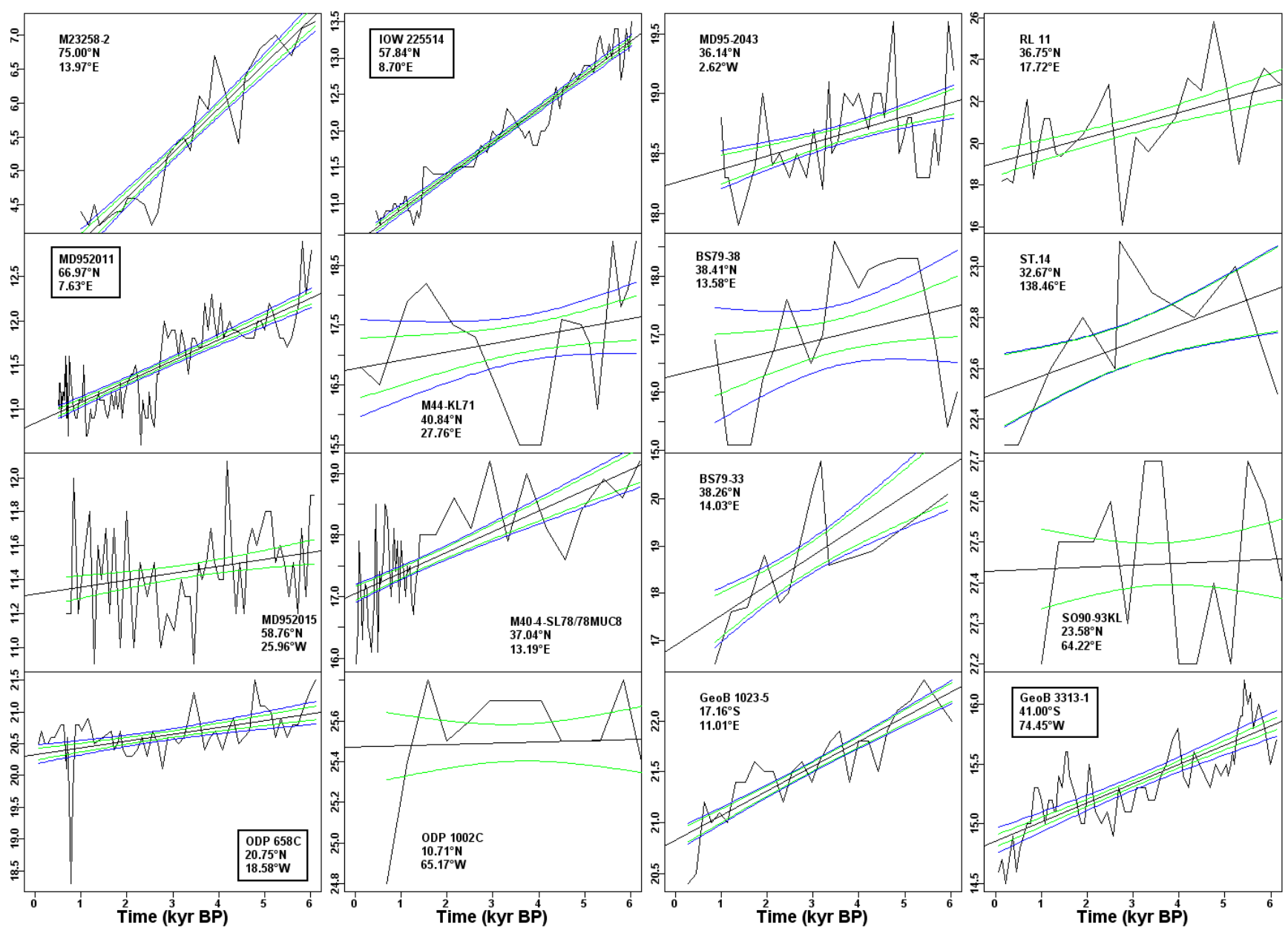

Fig. 2. As Fig. 1, but for cores with negative linear trends over the Holocene.

resolve the equatorial wave guide, and this resolution gradually decreases polewards until $30^{\circ}$ latitude to approximately $2.7^{\circ}$. As for the proxy reconstruction, we calculate the linear trends of the temperature simulation from the mid-Holocene to the present (6 to $0 \mathrm{kyr} \mathrm{BP}$ ).

In order to gain insight into the way different climate models perform when simulating the temperature evolution during the Holocene, we also analyse the modelled SST anomalies between 6 and $0 \mathrm{kyr}$ BP from simulations performed in the framework of the Paleoclimate Modelling Intercomparison Project Phase II (PMIP2) (Braconnot et al., 2007a,b). Assuming linearity of the mid- to late-Holocene temperature trends, the PMIP2 temperature anomalies can be compared to the reconstructed temperature trends. Our comparison comprises 14 experiments from 9 AOGCMs, of which some models performed two experiments, i.e. with and without interactive vegetation (Braconnot et al., 2007a, b). The models participating in PMIP2 represent coupled atmosphereocean models: CCSM3 (Otto-Bliesner et al., 2006), ECBiltCLIO-VECODE (Renssen et al., 2005), FGOALS-g1.0 (Yu et al., 2002, 2004), FOAM (Jacob et al., 2001), GISSmodelE
(Schmidt et al., 2006), MIROC3.2 (K-1 Model Developers, 2004), MRI-CGCM2.3.4 (Yukimoto et al., 2006), and UBRIS-HadCM3M2 (Gordon et al., 2000). Three models including a vegetation representation (ECBilt-CLIOVECODE, FOAM, and UBRIS-HadCM3M2) have been also used. For more detailed information on the set-up, we refer to Braconnot et al. (2007b).

Furthermore, we make the same analysis for the models participating in PMIP3 (Taylor et al., 2012; Braconnot et al., 2012), listed in Table 2.

In the first step of our analysis, we compare the observed proxy-based temperature trends to the simulated temperature trends at the core positions. As the habitat depth and the seasonality of the proxy recorder are not systematically known, we perform this comparison for simulated annual and seasonal mean temperatures and extract the temperature trends at each model level of the upper $100 \mathrm{~m}$ water depth of the ECHO-G model. In a second step, we estimate the sensitivity of the observed temperature trends to potential transient changes in the ecological behaviour of planktonic organisms: shifts in seasonality or habitat depth. 

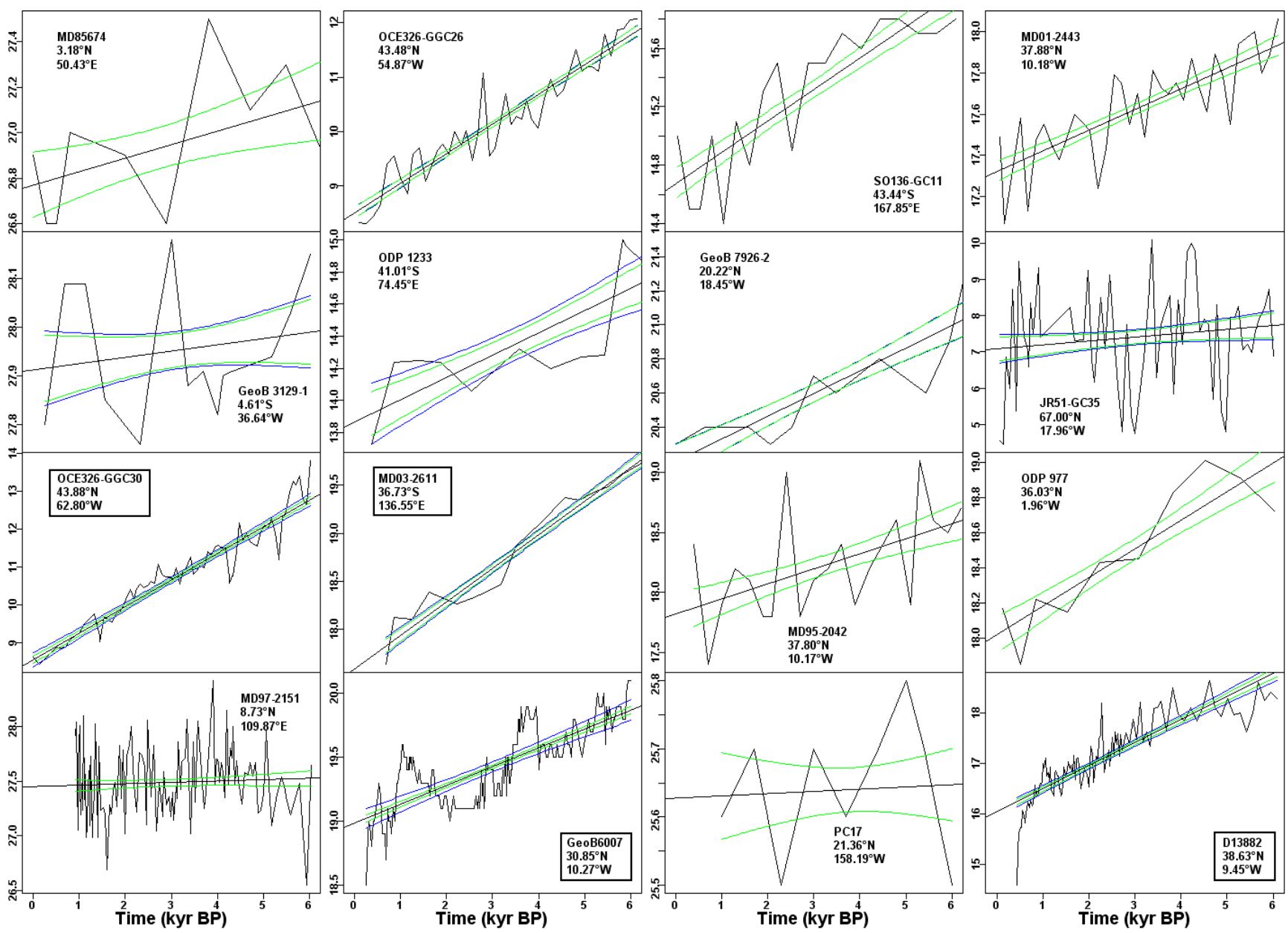

Fig. 3. As Fig. 2, continued.

For seasonality, we first extract the maximum seasonal temperature trend among the twelve months $\left({ }^{\circ} \mathrm{C} \mathrm{day}^{-1}\right)$ from the PI climate simulation for each core position. A lower limit of the seasonal shift that is needed to reconcile model simulation and proxy reconstruction is then calculated by dividing the residual between the simulated and reconstructed Holocene temperature trend by the maximum temperature trend described above. Such procedure only estimates the absolute value of the seasonality shift required to reconcile models and data, but its direction cannot be determined as a result of a lack of knowledge on the seasonality of the planktonic organisms. To make an example, a time shift of 30 days means that a seasonal correlation centred on JJA is then centred on JAS or MJJ. For present conditions, time shifts in the booming season of planktonic organisms are of the order of 15-60 days and can be affected by interannual to decadal temperature and circulation changes (e.g. Lohmann and Wiltshire, 2012). To derive a lower estimate for the shift in habitat depth, we analyse the vertical temperature gradient between the first two levels of the ocean $(10$ and $20 \mathrm{~m})$ in the PI climate model output at the core positions. We retrieve the shift in habitat depth similarly to the procedure of the time shift calculation, by dividing the difference between the simulated and reconstructed temperature trends by the vertical temperature gradient.

\section{Results}

\subsection{Holocene trends: data and model}

We compare the annual mean SST trends from the midHolocene to the present as simulated by the ECHO-G model and as estimated from alkenone and $\mathrm{Mg} / \mathrm{Ca}$ temperature proxies for the same time period (Fig. 5). We find that the general temperature pattern recorded by the alkenones is a warming in the tropics and the North Pacific Ocean. Cooling predominates in mid- and high latitudes of the North Atlantic Ocean and in the Southern Hemisphere midlatitudes. In many regions, such as the North Atlantic Ocean, the Mediterranean Sea, the northern Indian Ocean, and the western North Pacific Ocean, there is a good agreement between the model and alkenone data with respect to the 

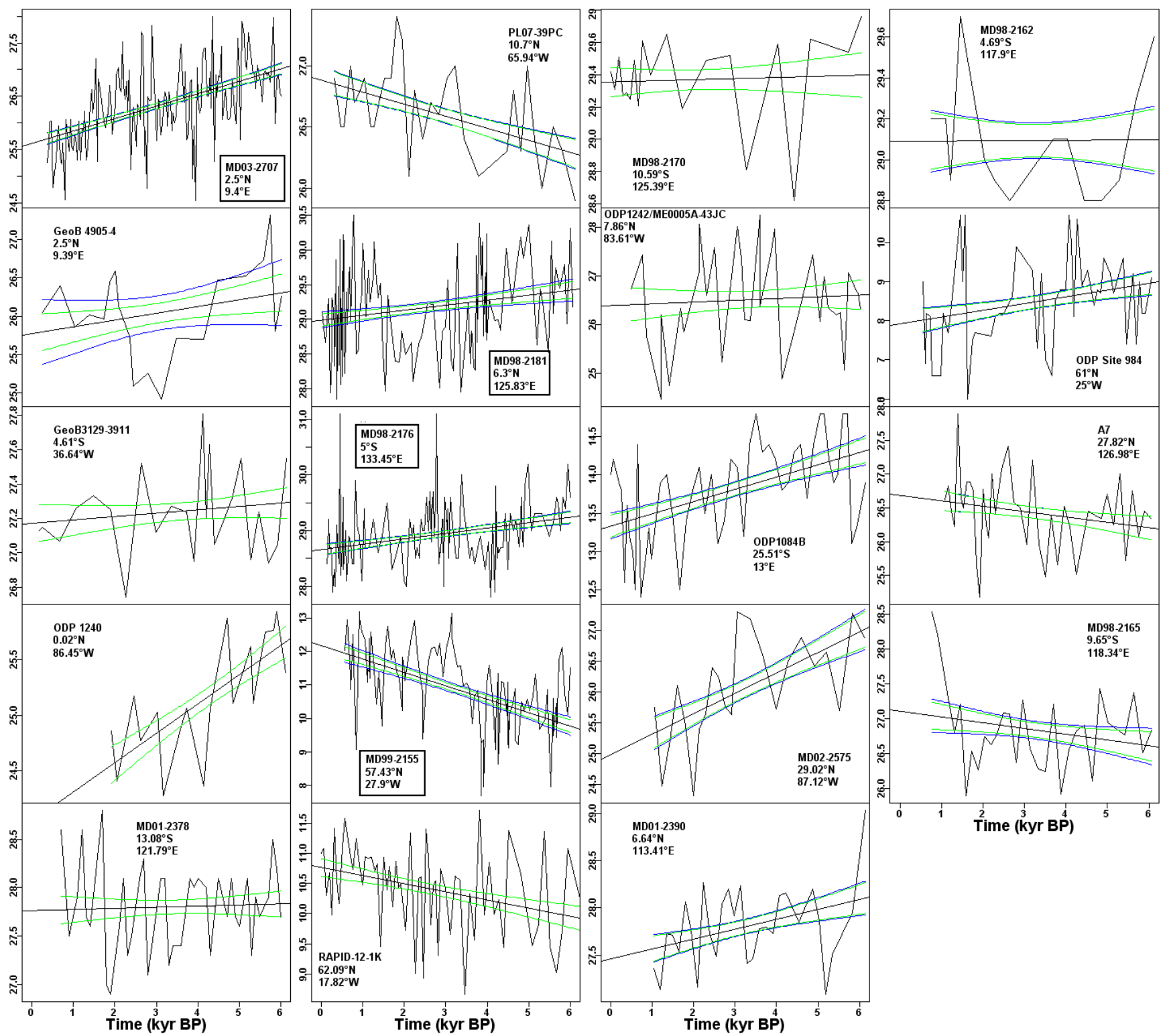

Fig. 4. As Fig. 1, but for $\mathrm{Mg} / \mathrm{Ca}$ records.

spatial pattern of the temperature trend (Fig. 5). Globally, the alkenone and simulated SST trends are significantly correlated $(R=0.49, p<0.05)$. Yet, the amplitudes of recorded and simulated temperature trends often differ, with proxies generally showing larger SST changes during the Holocene. A scatter plot of the modelled SST trends as simulated by the ECHO-G model versus alkenone-based SST trends (Fig. 6a) shows that only at few locations do the alkenone reconstructions and the model simulations bear comparable temperature trends. The correlation between the modelled and $\mathrm{Mg} / \mathrm{Ca}$-based SST trends is negative and not significant $(R=-0.31, p>0.05)$.

To analyse the potential influence of the seasonality on the model-data comparison, seasonal variations of the simulated monthly temperature trends are shown as vertical bars in Fig. 6. Of the 52 alkenone records, only $22(\sim 42 \%$ of the total number of records) are in agreement with the model trend at some time during the year (Fig. 6a). Out of the other 30 ( $\sim 58 \%)$ data markers, $9(\sim 17 \%$ of the total number of records) show a difference of more than $2^{\circ} \mathrm{C}$.

A similar analysis for $\mathrm{Mg} / \mathrm{Ca}$-based SSTs indicates that approximately $53 \%$ of the cores agree with the model simulation at some time during the year (Fig. 6b). Of the 9 $(\sim 47 \%)$ data markers that do not match with the model simulation, $2(\sim 11 \%)$ differ by more than $2{ }^{\circ} \mathrm{C}$ (Fig. $\left.6 \mathrm{~b}\right)$. Temperature trends are larger in the alkenone $\left(-4\right.$ to $\left.2^{\circ} \mathrm{C}\right)$ than in the $\mathrm{Mg} / \mathrm{Ca}\left(-2\right.$ to $2^{\circ} \mathrm{C}$ ) reconstructions. This might be also caused by the different core positions of both proxies. In our 


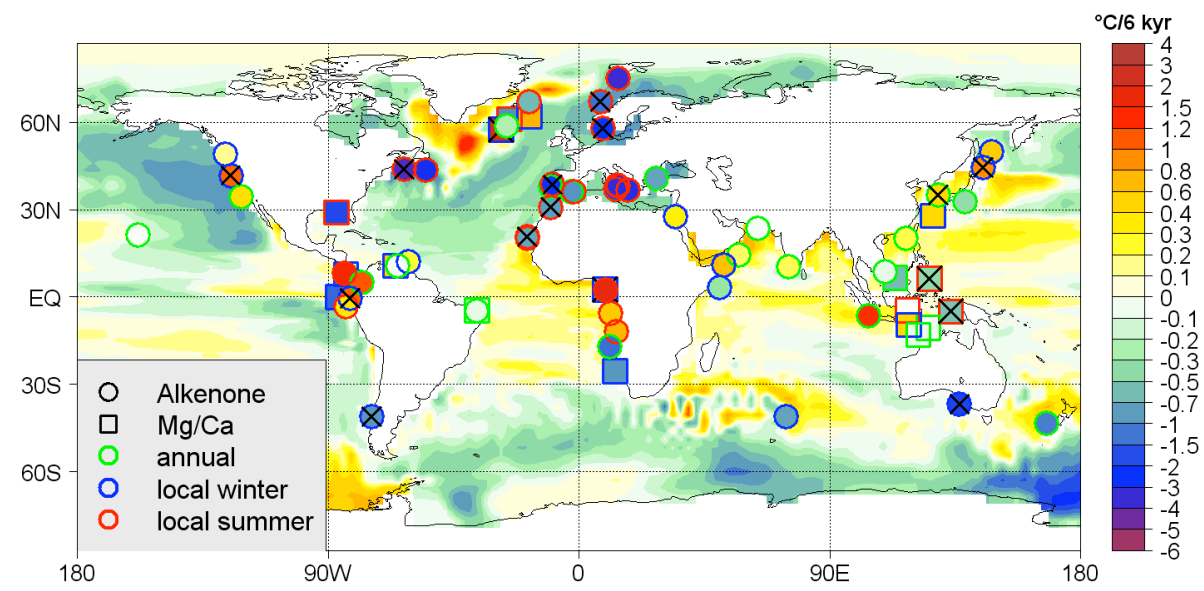

Fig. 5. Global SST trends of the annual mean ECHO-G model output, and local temperature trends based on alkenone and Mg/Ca reconstructions. The circles and squares localize the alkenone and $\mathrm{Mg} / \mathrm{Ca}$ records, respectively, the colours that fill the circles/squares show the temperature trend they record. The border colours of the circles/squares represent the annual mean/season in which the reconstruction agrees best with the model simulation. Crosses indicate the record locations where the test of the regression residuals fails to show randomness.
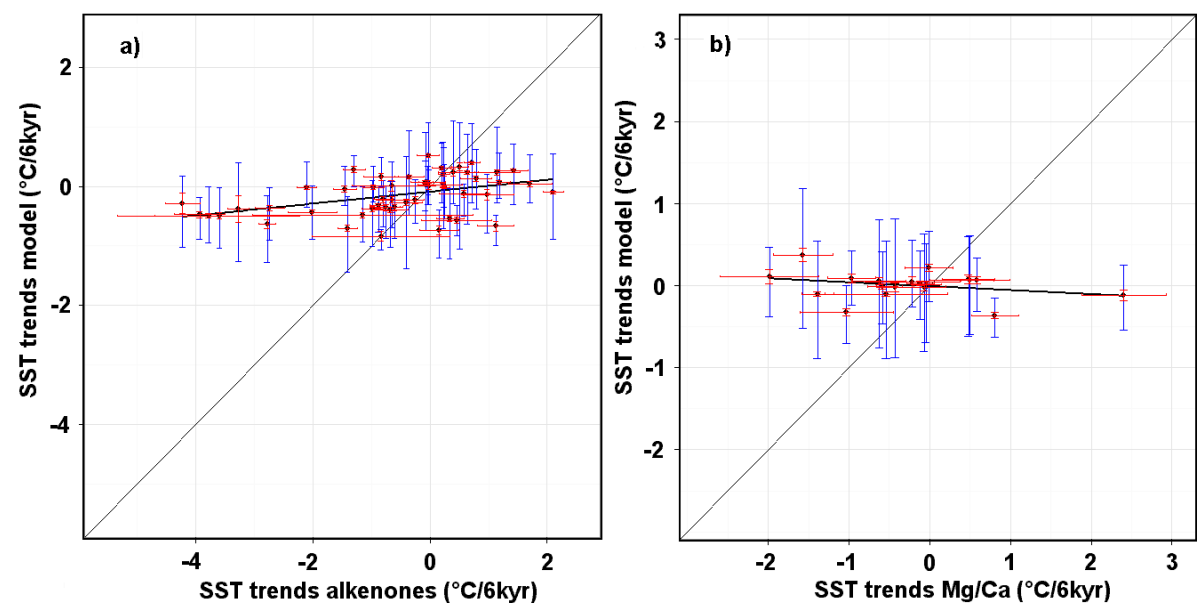

Fig. 6. (a) Alkenone-based temperature trends plotted against annual mean SST trends derived from the ECHO-G model. As (a), but for $\mathrm{Mg} / \mathrm{Ca}$-based temperature trends. The solid thick lines represent the 1:1 line for a match of modelled and reconstructed trends. The thin lines represent the regression of modelled and reconstructed trends. Red bars represent the standard error of the slope, and blue bars show the modelled seasonal range (maximum and minimum seasonal temperature).

dataset, alkenone records are more abundant at high latitudes while $\mathrm{Mg} / \mathrm{Ca}$ records are more abundant in low latitudes. The data with more than $2^{\circ} \mathrm{C}$ (Fig. 6a) are mainly at high latitudes. We expect that the alkenone method has its limitations in these areas (e.g. Conte et al., 1998, 2001; Calvo et al., 2002). The magnitude of the modelled SST trends at core locations is, however, limited to the range from -1 to $1{ }^{\circ} \mathrm{C}$, which means that the model underestimates the trends as compared to both the alkenone and $\mathrm{Mg} / \mathrm{Ca}$ reconstructions.

\subsection{Residuals and error bars}

We test whether a linear model is appropriate to describe the shape of the Holocene trends. The insolation changes are not linear in time, and non-linear reactions of the climate system might additionally cause deviations from a linear evolution with time. In the sediment records, some cores, for example alkenone record BS79-38, show deviations from linearity. This is especially true for alkenone records and less pronounced for the $\mathrm{Mg} / \mathrm{Ca}$ records. One cannot exclude that this occurs by chance as the alkenone residuals are autocorrelated in time, a point we will discuss in more detail later.

We analyse the residual plots (standardized residuals of the fit relative to the fitted values) of all sediment records for the alkenones and $\mathrm{Mg} / \mathrm{Ca}$, as well as the corresponding AOGCM time series (not shown). Across the cores, no clear common pattern in the deviations from linearity is visible which would ask for a non-parametric analysis. We further tested if other 
Table 2. List of the models in PMIP3.

\begin{tabular}{|c|c|c|c|c|}
\hline \multirow[b]{2}{*}{ Model name } & \multicolumn{2}{|c|}{ Resolution } & \multirow[b]{2}{*}{ Reference for model } & \multirow[b]{2}{*}{ Modelling centre (or group) } \\
\hline & Atmosphere & Ocean & & \\
\hline BCC-CSM1.1 & $\begin{array}{l}\text { T42 }\left(\sim 2.8^{\circ} \times 2.8^{\circ}\right) \\
\text { L26 }\end{array}$ & $\begin{array}{l}360 \times 232 \\
\mathrm{~L} 40\end{array}$ & Wu et al. (2013) & $\begin{array}{l}\text { Beijing Climate Center, China Meteorological } \\
\text { Administration }\end{array}$ \\
\hline CCSM4 & $0.9^{\circ} \times 1.25^{\circ} \mathrm{L} 26$ & $320 \times 384 \mathrm{~L} 60$ & Gent et al. (2011) & National Center for Atmospheric Research \\
\hline CNRM-CM5 & $\begin{array}{l}\mathrm{T} 127\left(1.4^{\circ} \times 1.4^{\circ}\right) \\
\mathrm{L} 31\end{array}$ & $\begin{array}{l}362 \times 292 \\
\mathrm{~L} 42\end{array}$ & Voldoire et al. (2012) & $\begin{array}{l}\text { Centre National de Recherches Météorologiques/ } \\
\text { Centre Européen de Recherche et de Formation } \\
\text { Avancée en Calcul Scientifique }\end{array}$ \\
\hline CSIRO-Mk3-6-0 & $\mathrm{T} 63\left(1.9^{\circ} \times 1.9^{\circ}\right) \mathrm{L} 18$ & $192 \times 192 \mathrm{~L} 31$ & Collier et al. (2011) & $\begin{array}{l}\text { Commonwealth Scientific and Industrial Research } \\
\text { Organization in collaboration with Queensland } \\
\text { Climate Change Centre of Excellence }\end{array}$ \\
\hline CSIRO-Mk3L-1-2 & $\begin{array}{l}\mathrm{R} 21\left(5.625^{\circ} \times 3.8^{\circ}\right) \\
\mathrm{L} 18\end{array}$ & $128 \times 112 \mathrm{~L} 21$ & & University of New South Wales \\
\hline GISS-E2-R & $2^{\circ} \times 2.5^{\circ} \mathrm{L} 40$ & $288 \times 180 \mathrm{~L} 32$ & $\begin{array}{l}\text { Russell et al. (1995) } \\
\text { Schmidt et al. (2006) }\end{array}$ & NASA Goddard Institute for Space Studies \\
\hline HadGEM2-CC & $1.875^{\circ} \times 1.25^{\circ} \mathrm{L} 60$ & $360 \times 216 \mathrm{~L} 40$ & $\begin{array}{l}\text { Bellouin et al. (2007) } \\
\text { Collins et al. (2008) }\end{array}$ & $\begin{array}{l}\text { Met Office Hadley Centre (additional HadGEM2-ES } \\
\text { realizations contributed by Instituto Nacional de } \\
\text { Pesquisas Espaciais) }\end{array}$ \\
\hline HadGEM2-ES & $1.875^{\circ} \times 1.25^{\circ} \mathrm{L} 38$ & $360 \times 216 \mathrm{~L} 40$ & $\begin{array}{l}\text { Bellouin et al. (2007) } \\
\text { Collins et al. (2008) }\end{array}$ & $\begin{array}{l}\text { Met Office Hadley Centre (additional HadGEM2-ES } \\
\text { realizations contributed by Instituto Nacional de } \\
\text { Pesquisas Espaciais) }\end{array}$ \\
\hline IPSL-CM5A-LR & $1.875^{\circ} \times 3.75^{\circ} \mathrm{L} 39$ & $182 \times 149 \mathrm{~L} 31$ & Dufresne et al. (2013) & Institut Pierre-Simon Laplace \\
\hline KCM1-2-2 & $\begin{array}{l}\mathrm{T} 31\left(\sim 3.75^{\circ} \times 3.75^{\circ}\right) \\
\mathrm{L} 19\end{array}$ & $182 \times 149 \mathrm{~L} 31$ & $\begin{array}{l}\text { Park and Latif (2008) } \\
\text { Park et al. (2009) }\end{array}$ & Christian-Albrechts University, Kiel \\
\hline MPI-ESM-P & $\mathrm{T} 63\left(1.9^{\circ} \times 1.9^{\circ}\right) \mathrm{L} 47$ & $256 \times 220 \mathrm{~L} 40$ & Giorgetta et al. (2012) & $\begin{array}{l}\text { Max-Planck-Institut für Meteorologie (Max Planck } \\
\text { Institute for Meteorology) }\end{array}$ \\
\hline COSMOS-aso & $\begin{array}{l}\text { T31 }\left(\sim 3.75^{\circ} \times 3.75^{\circ}\right) \\
\text { L19 }\end{array}$ & $120 \times 101 \mathrm{~L} 40$ & $\begin{array}{l}\text { Roeckner et al. (2003) } \\
\text { Jungclaus et al. (2006) } \\
\text { Raddatz et al. (2007) }\end{array}$ & $\begin{array}{l}\text { Alfred Wegner Institute, Helmholtz Centre for Polar } \\
\text { and Marine Research }\end{array}$ \\
\hline MRI-CGCM3 & TL159L48 & $364 \times 368$ L5 1 & Yukimoto et al. (2012) & Meteorological Research Institute \\
\hline
\end{tabular}

parametric models as polynomial models are more appropriate than our linear model: whereas a polynomial model, as expected, results in a higher explained variance, no relation between the deviations from linearity was found in the GCM and the proxies. In the case of fitting a second order polynomial, the non-linear terms between model and data are uncorrelated.

We therefore continue to favour the linear model. While we acknowledge that this is not a perfect description of the climate response, the linear models provide a good metric to summarize the main behaviour.

In order to further assess the randomness of the proxy linear regressions' residuals, we conduct a formal test on each proxy record. The runs test is applied on the residuals of each linear regression and gives a $p$ value for each regression. We consider 0.05 as our level of significance meaning that a $p$ value $<0.05$ rejects the null hypothesis that the data shows no relationship and therefore the residuals are not random but dependent, while a $p$ value $>0.05$ signifies randomness (the data is independent).
The test applied on the alkenone linear regressions' residuals shows that there are 40 records out of 52 for which the residuals show randomness, the other 12 being dependent when choosing the $p$ value of 0.05 . For $\mathrm{Mg} / \mathrm{Ca}$ there are 4 dependent data records out of 19 . For reference, we mark them in all figures containing the proxy data by crosses or by boxing the name of the records. We calculated furthermore the correlations without the records that did not pass the test: Table S1 in the Supplement gives similar values as Table 3. No spatial pattern of the dependent data records is observed.

As we mentioned before, these analyses also show that the residuals are not independent in time for the alkenone records. This is expected as elements of the climate system, especially the oceans, provide some memory. Further, the recording process, as mixing of the sediment by bioturbation, might further increase the autocorrelation. We therefore account for serial correlation by estimating the effective degrees of freedoms (von Storch and Zwiers, 1999; Mudelsee, 2010). The linear models and correlation coefficients are calculated on the raw data without interpolation. To estimate the bias of the uncertainty estimates caused by serial correlation 
Table 3. List of the correlation between modelled and reconstructed trends (weighted and unweighted).

\begin{tabular}{|c|c|c|c|c|}
\hline & \multicolumn{2}{|c|}{ Alkenones } & \multicolumn{2}{|c|}{$\mathrm{Mg} / \mathrm{Ca}$} \\
\hline & $R$ & $R$, weighted & $R$ & $R$, weighted \\
\hline Annual mean & $0.45, p<0.05$ & $0.53, p<0.05$ & $-0.28, p>0.05$ & $-0.18, p>0.05$ \\
\hline Local winter & $0.14, p>0.05$ & $0.25, p>0.05$ & $0.17, p>0.05$ & $0.38, p>0.05$ \\
\hline Local summer & $0.44, p<0.05$ & $0.42, p<0.05$ & $-0.56, p<0.05$ & $-0.74, p<0.05$ \\
\hline
\end{tabular}

of the data, autocorrelation estimates are needed. For simplicity, the autocorrelation coefficients are calculated on the non-equidistant data. We assume that the process causing the serial correlation would be stationary against the index of the measurement, while the true process might act on depth, time or the measurement index. Monte Carlo simulations using the true spacing of the datasets show that the method even leads to reasonable results when a linear relation and autocorrelated noise against time are assumed (Mudelsee, 2010; Sect. 2.1.2). An alternative method of interpolating all datasets on regular time spacing leads to similar results but less accurate slope estimates (as determined in Monte Carlo experiments were the true slope is known). The serial correlation increases the uncertainty of the slope estimates, especially for the $U_{37}^{K^{\prime}}$ records (Figs. 1-3). We furthermore find that the uncertainty in the simulated SST trends is very small. We include the uncertainty in the trend analysis by adding error bars in Figs. 1-4.

\subsection{PMIP simulations: comparison with proxy-derived SST trends}

To test whether the above-described relation between proxyderived and modelled SSTs are model-dependent, we analyse simulations from the PMIP2 and PMIP3 multi-model experiment (see Sect. 2). Therefore, we compare the difference between the mid-Holocene and PI simulated SST fields to the alkenone- and $\mathrm{Mg} / \mathrm{Ca}$-based SST trends (Fig. 7 for PMIP2; Fig. 8 for PMIP3), as described above for the transient ECHO-G simulations.

In general, the Holocene trends simulated by the models participating in PMIP2, PMIP3, and the ECHO-G transient runs are comparable. We perform this comparison on a global scale for modelled vs. alkenone-derived SSTs (Figs. 7a and 8a) and modelled vs. Mg/Ca-based SSTs (Figs. $7 \mathrm{~b}$ and $8 \mathrm{~b}$ ) separately. Only a few data markers are close to the unity slope line. The agreement between the models and the SST reconstructions is similar to the case of the ECHO-G model (Fig. 6). Because of space limitations, we do not show all individual model anomalies and their (dis)agreement with the alkenone-derived SST trends. Instead, the median (Fig. 9a and b) is used to display the common signal. For example, for our list of PMIP2 models (Fig. 9a), it is defined as the value of the 12th ensemble member out of 24 members that are ordered according to ranked values. This reduces features that vary amongst the members and are therefore likely to be regarded as model specific and less reliable. Indeed, the model-data agreement is largest for the ensemble median (Fig. 9a and b) as compared to each individual member. However, all of the considered models underestimate the temperature trends when compared to the SST trends as recorded by the alkenones by more than a factor of two (Figs. 7a and 8a). Mg/Ca shows again no relationship to the simulated SST anomalies (Figs. $7 \mathrm{~b}$ and $8 \mathrm{~b}$ ). Since the results of the PMIP runs and the ECHO-G simulation are similar, we continue on to the habitat depth and seasonality in ECHO-G.

\subsection{Seasonality in ECHO-G}

A comparison of SST trends of each proxy with local summer, local winter and annual mean SST trends, as simulated by ECHO-G, indicates which season shows the best agreement between model and proxy reconstruction (Fig. 5). The local summer and winter is defined by the warmest and coldest month. In the North Atlantic Ocean, the best agreement is obtained for local summer (Fig. 5). In other areas, there is no clear evidence for a preferred season. Some cores in close proximity with each other show the best agreement for different seasons in the model. This suggests that the best agreement with a specific season might not always be caused by the seasonality in the recording process.

Figure 10 compares the temperature trends derived from alkenone and $\mathrm{Mg} / \mathrm{Ca}$ records to those calculated from the evolution of the warmest (local summer) and coldest (local winter) month of each year from the mid-Holocene to the present. The correlation between the alkenone proxy record and the climate simulation is higher for local summer $(R=0.44, p<0.05)$ than for winter $(R=0.14, p>0.05)$, but lower than for the annual mean $(R=0.49, p<0.05)$. In the North Atlantic Ocean, the agreement between the reconstructed and the simulated SST trends is still stronger for the local summer than for the annual mean, because the simulated cooling trend is much more pronounced for summer than for the annual mean (Fig. 10b). For $\mathrm{Mg} / \mathrm{Ca}$, there is a positive but insignificant correlation for the winter mean $(R=0.17, p>0.05)$, and negative and significant correlation for the summer mean $(R=-0.56, p<0.05)$ and the annual mean $(R=-0.31, p>0.05)$. 

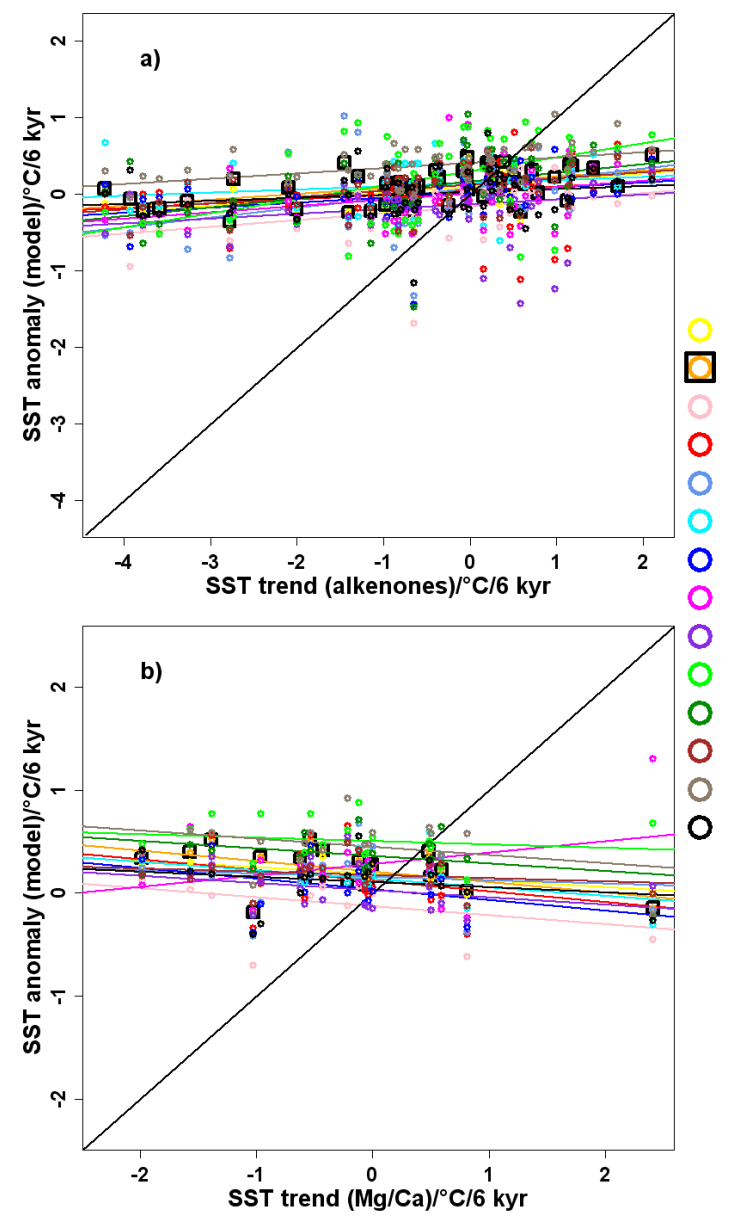

ensemble mean

ensemble median mean

ECBilt-CLIO-VECODE (oav)

- FOAM (oav)

- UBRIS-HadCM3M2 (oav)

- CCSM3 (oa)

- ECBilt-CLIO-VECODE (oa)

- FGOALS-g1.0 (oa)

- FOAM (oa)

- GISSmodelE (oa)

- MIROC3.2 (oa)

- MRI-CGCM2.3.4fa (oa)

- MRI-CGCM2.3.4nfa (oa)

o UBRIS-HadCM3M2 (oa)

Fig. 7. (a) Global alkenone-based SST trends compared to simulated annual mean SST anomalies in the models listed in PMIP2. The black squares represent the ensemble median mean and the colours correspond to a specific model. (b) Global Mg/Ca-based SST trends compared to the models of the PMIP2 annual mean SST anomalies.

To consider the uncertainties in the SST trends in the model-data comparison, we calculate the weighted correlation between model and proxy data trends. The Pearson correlation coefficients were calculated for annual, local winter, and local summer trends. The weights were calculated with $1 \mathrm{sd}^{2}$, where sd is the standard error of the slope in the proxy SSTs. The weighting of the trends with their uncertainty increases the positive correlations between simulated and observed trend patterns in all cases except for local summer, where correlation is nearly unaffected by the weighting (Table 3).

\subsection{Habitat depth in ECHO-G}

The analyses described so far focused on the model-data comparison at the sea surface. Planktonic organisms are however known to be able to move in the water column (e.g. Conte et a., 2006). In order to depict whether deeper model layers would be in better agreement with the temperature reconstruction, the proxy records were compared to the model for different layers of the upper $100 \mathrm{~m}$ of the ocean $(10,20,52,75$, and $100 \mathrm{~m})$. Layers below these depths can be ignored, since alkenone-producing organisms require sunlight for photosynthesis and are therefore strictly restricted to the euphotic zone. For the $\mathrm{Mg} / \mathrm{Ca}$ ratio, we also consider only the same upper layers, since the species that are represented in the proxy database used in our study (Globigerinoides ruber, Globigerina bulloides, and Neogloboquadrina pachyderma) are considered as being surface-dwelling foraminifera (Ostermann et al., 2001; Schiebel et al., 1997; Wang et al., 1995).

Figure 11a shows the depths of best fit between the modelled SST trends and the alkenone- and $\mathrm{Mg} / \mathrm{Ca}$-based SST trends. For alkenones, about a third of the records best agree with the upper level of the ocean, with the highest correlations being present in the upper $10 \mathrm{~m}(\sim 33 \%)$. The other $\sim 67 \%$ of the records best agree with deeper layers; of those $38 \%$ are located between 10 and $75 \mathrm{~m}$. In general, the number of cores that agree with modelled temperature trends decreases with depth (Table 4). 

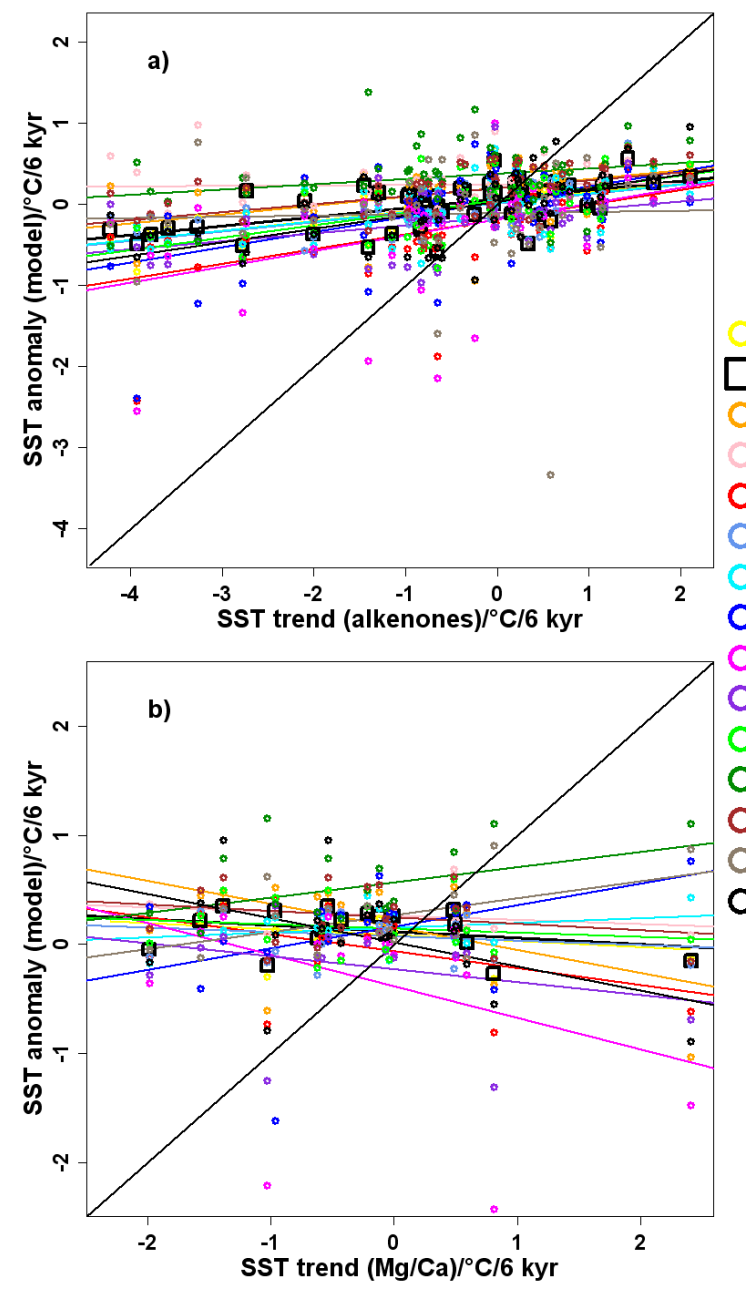

ensemble mean

ensemble median mean

BCC-CSM1.1

CCSM4

O CNRM-CM5

C CSIRO-Mk3-6-0

CSIRO-Mk3L-1-2

O GISS-E2-R

O HadGEM2-CC

- HadGEM2-ES

- IPSL-CM5A-LR

O KCM1-2-2

O MPI-ESM-P

- COSMOS-aso

o MRI-CGCM3

Fig. 8. As Fig. 7, but for PMIP3.

Table 4. Best fit for alkenone and $\mathrm{Mg} / \mathrm{Ca}$ records for different layers of the ocean.

\begin{tabular}{llll}
\hline Depth (m) & 10 & $10-30$ & $30-50$ \\
\hline Alkenone records \% & $\sim 34$ & $\sim 12$ & $\sim 10$ \\
Mg/Ca records \% & $\sim 32$ & $\sim 5$ & $\sim 11$ \\
\hline
\end{tabular}

For $\mathrm{Mg} / \mathrm{Ca}$ ratios, $\sim 32 \%$ of the records fit best to the modelled temperature trends at $10 \mathrm{~m}$ depth. The remainder of $68 \%$ fit best to deeper layers, of which $32 \%$ show best agreement with layers between 10 to $75 \mathrm{~m}$. Figure $11 \mathrm{~b}$ shows a common pattern of the preferred depth for alkenones, which might be linked to the depth where annual average nitrate concentrations reach high levels according to a modern nutrient climatology (Conkright and Boyer, 2002). This suggests that the nutrient supply from deeper waters is an important influence on the alkenone production as hypothesized by Ohkouchi et al. (1999). Although Fig. 11b and c do not account for zonal oceanic heterogeneities, Fig. 11b and $\mathrm{c}$ capture at first-order the ecological preference for algae ecological niches found close to the surface at low and high latitudes (due to the influences of upwelling and of penetration of sunlight into the subsurface layers, respectively), while the midlatitude regions where the nutricline is found deeper show an increase in the depth where model and data agree best (Fig. 11b). We note that not all red and blue points are pairwise in the panel because of missing data and the restriction to the upper $300 \mathrm{~m}$ in the panels.

\subsection{Changes in the recording season and habitat depth in ECHO-G}

While choosing specific depths and seasons in the model simulations decreases the mismatch between reconstructed and simulated trends, the amplitude of the simulated trends is still smaller than of the reconstructed trends (Figs. 5 and 6). We therefore evaluate two potential parameters that might be able to partly explain the misfits found in the modeldata comparison: a time shift in the recording season and a 


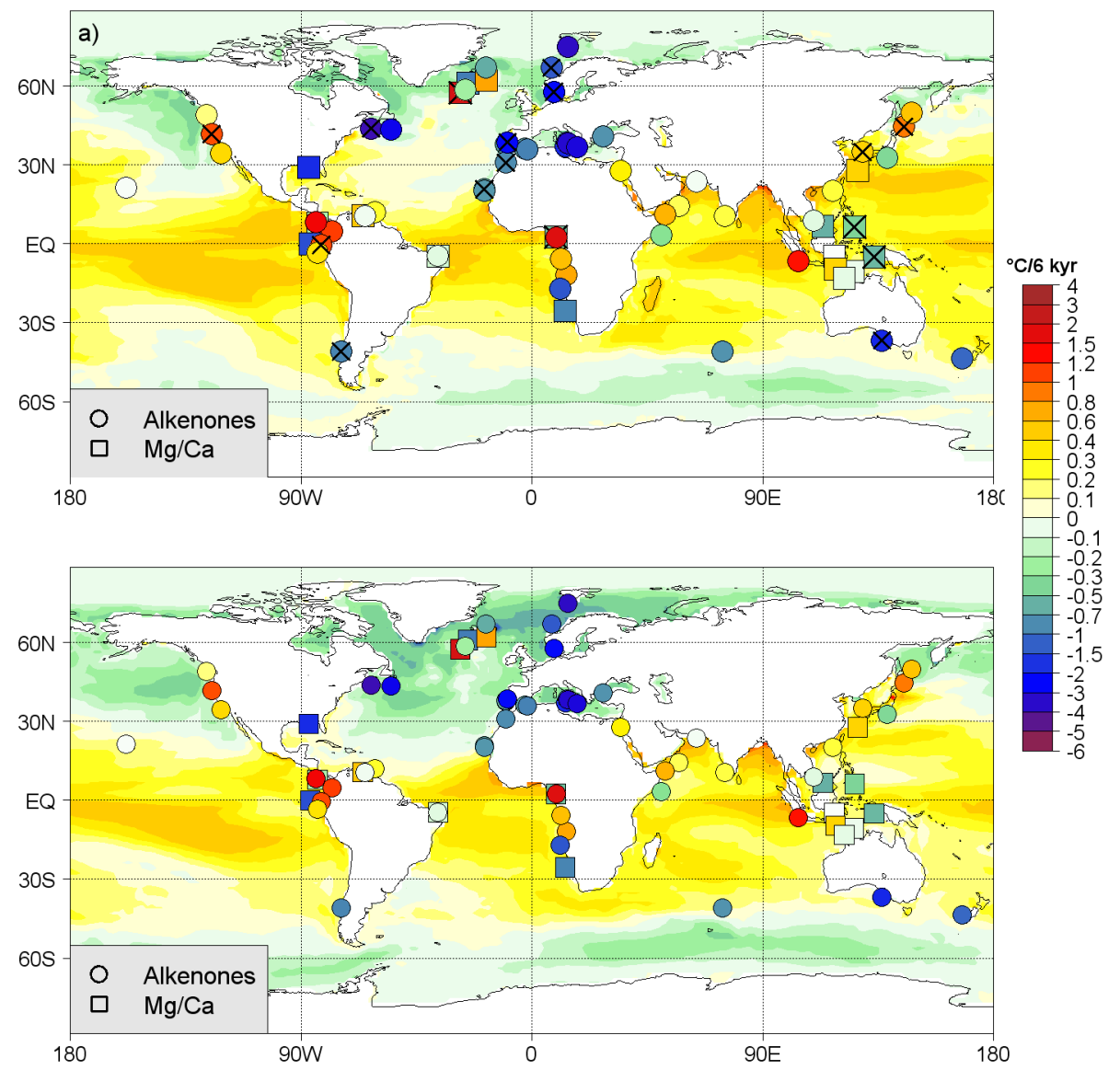

Fig. 9. Global reconstructed SST trends compared to simulated annual mean SST anomalies as calculated from the ensemble median mean of the models listed in PMIP2 (a) and PMIP3 (b). Crosses in (a) indicate the record locations where the test of the regression residuals fails to show randomness.

change in the habitat depth of the recorder (Figs. 12 and 13). The model-alkenone data disagreement would vanish for up to $37 \%$ of the records by considering a potential vertical shift of the habitat depth of the proxy-producing organism in the water column by less than $20 \mathrm{~m}$. For up to $52 \%$ of the alkenone records, a time shift in the blooming season of less than 14 days could explain the model-data mismatch (for the seasonality of the modelled SSTs, see Figs. S1-S4 in the Supplement). In total, up to $62 \%$ of the records can be explained by at least one of the two shifted parameters, whereas the remaining $38 \%$ of the cores cannot be explained by any of these potential parameters. We further note that for $38 \%$ of the records, the ambient temperature exceeds the calibration range $6-25^{\circ} \mathrm{C}$ for which alkenones are most sensitive to SST (e.g. Conte et al., 2006). In tropical warm pools and polar regions, the ambient water temperature induces only small changes in the $U_{37}^{K^{\prime}}$ index, reducing the sensitivity of alkenone palaeothermometry for these regions (Sonzogni et al., 1997; Mix et al., 2000; Conte et al., 2006); therefore the recorded temperature proxy at those locations might be problematic. However, as the sensitivity of $U_{37}^{K^{\prime}}$ on temperature changes seems to be reduced in these tails of the calibration, we do not expect that this mechanism leads to an overestimation of the trends.

The same analysis performed for the $\mathrm{Mg} / \mathrm{Ca}$ records (Fig. 13) shows that up to $\sim 26 \%$ of the records could potentially be reconciled with the model simulation if we consider a shift in habitat depth of up to $20 \mathrm{~m}$. For up to $21 \%$ of the records, a shift in recording season of less than 14 days could explain the disagreement between model simulation and data reconstruction. The remainder $58 \%$ of the $\mathrm{Mg} / \mathrm{Ca}$ records cannot be explained by any of these two parameters. For an overview on the agreement between model and proxy data, we refer to Table 5 .

\section{Discussion}

Our analyses show that, in general, the model and alkenonebased Holocene SST trends show a similar pattern, but the amplitude of the modelled temperature trends are weaker when compared to the proxy records. The $\mathrm{Mg} / \mathrm{Ca}-$ reconstructed temperature trends do not show a positive 
Table 5. Overview on the agreement between model and proxy data. We list cores that agree with the model simulation at some time during the year and summarize the number of cores that could be reconciled with the model simulation by assumed shifts of $<20 \mathrm{~m}$ of the habitat depth and $<14$ days of the blooming season. We also list cores that show a difference of more than $2{ }^{\circ} \mathrm{C}$ to the model simulation, and note cores that might be biased by calibration uncertainties.

\begin{tabular}{lcccccc}
\hline & $\begin{array}{c}\text { Cores } \\
\text { that } \\
\text { agree } \\
\text { during } \\
\text { annual } \\
\text { cycle }\end{array}$ & $\begin{array}{c}\text { Shift in } \\
\text { depth of } \\
<20 \mathrm{~m}\end{array}$ & $\begin{array}{c}\text { Shift in } \\
\text { time } \\
\text { of }<14 \\
\text { days }\end{array}$ & $\begin{array}{c}\text { Shifts } \\
<20 \mathrm{~m} \\
\text { and } \\
\end{array}$ & $\begin{array}{c}\text { Model- } \\
\text { data } \\
\text { difference } \\
>2{ }^{\circ} \mathrm{C}\end{array}$ & $\begin{array}{c}\text { Calibration } \\
\text { uncertainties }\end{array}$ \\
& & & & & \\
\hline Alkenone records $\%$ & $\sim 42$ & $\sim 37$ & $\sim 52$ & $\sim 62$ & $\sim 17$ & $\sim 38$ \\
$\mathrm{Mg} /$ Ca records $\%$ & $\sim 53$ & $\sim 26$ & $\sim 21$ & $\sim 42$ & $\sim 11$ & N. A. \\
\hline
\end{tabular}

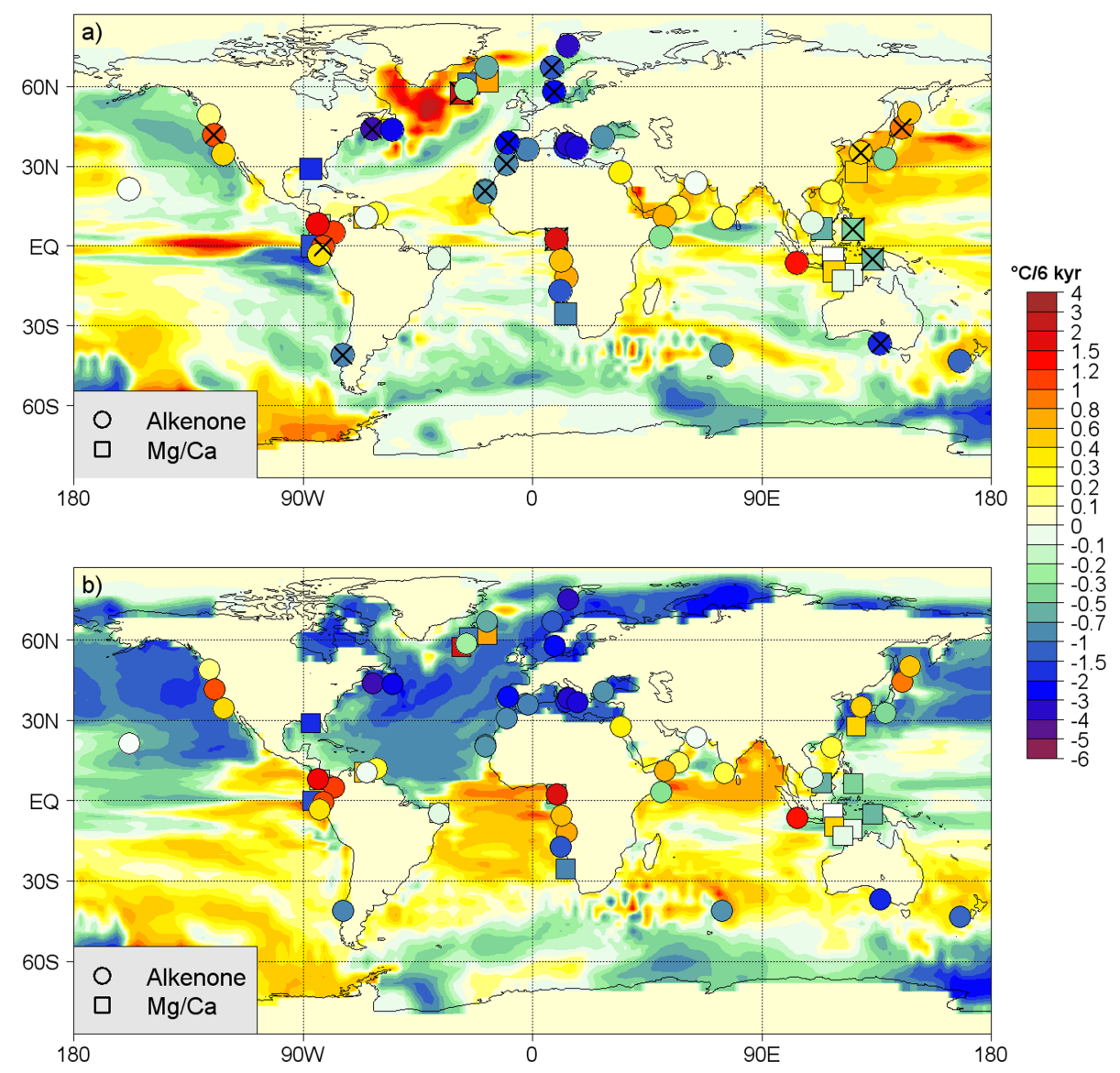

Fig. 10. Local temperature trends based on proxy reconstructions and seasonal SST trends taken from the ECHO-G climate simulation for (a) local winter and (b) local summer. The circles and squares represent the locations of alkenone and $\mathrm{Mg} / \mathrm{Ca}$ records, respectively; the fill-colour of the data marker represents the recorded temperature trend. Crosses in (a) indicate the record locations where the test of the regression residuals fails to show randomness.

relation to the simulated trend pattern. The observed mismatch between the proxy records and the model simulations might be caused by model deficiencies as well as by biased and/or misinterpreted proxy records. In the following, we will discuss several hypotheses.

\subsection{Recorder system: potential seasonal biases}

The deviation between climate simulations and proxy records could be at least partly attributed to the way by which proxies record the temperature signal, and how this information is interpreted. Systematic changes in the living season 


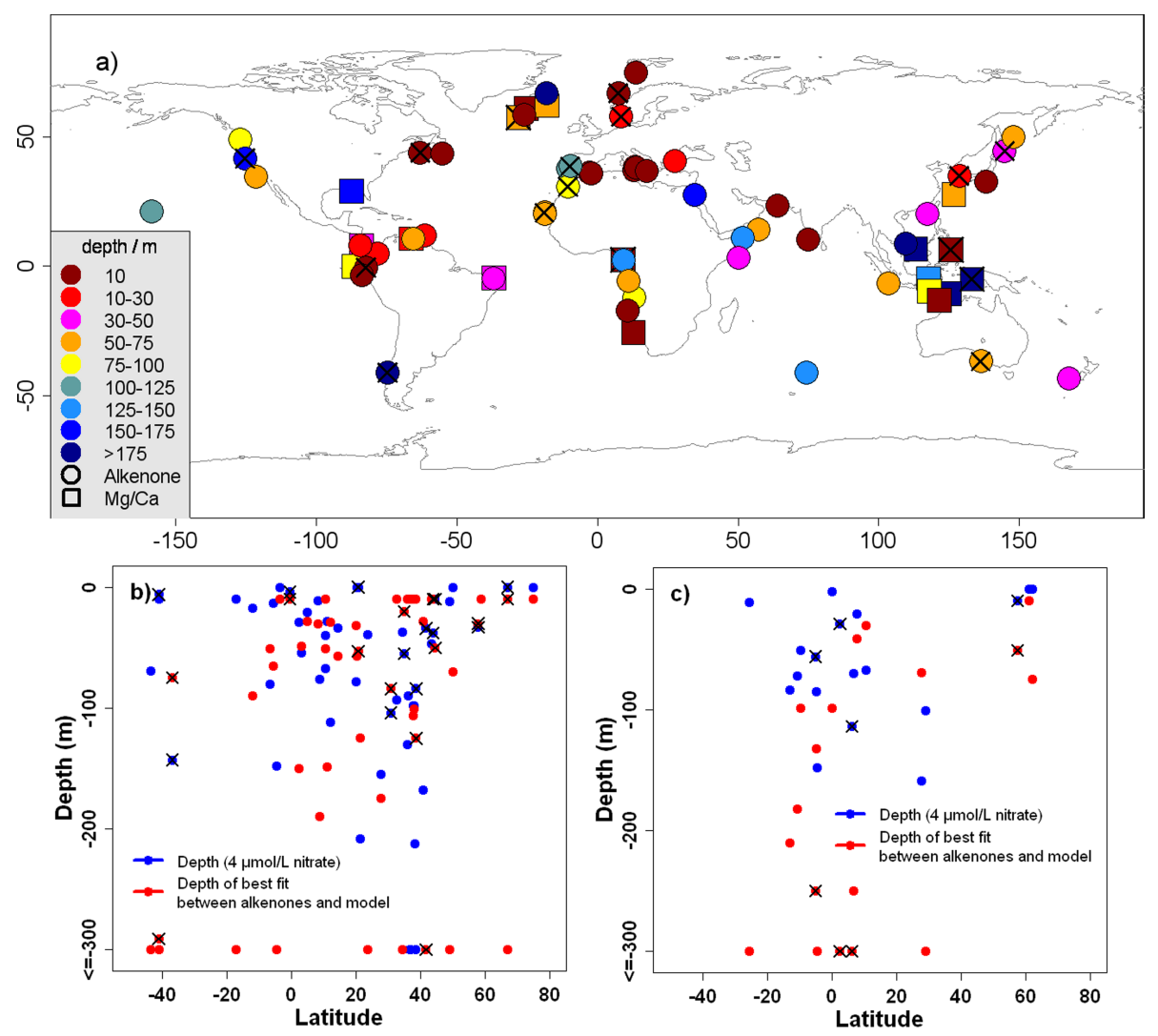

Fig. 11. (a) Depth for best agreement between alkenone and $\mathrm{Mg} / \mathrm{Ca}$ temperature reconstructions and model simulation. The filled circles/squares indicate the depth interval in which the best fit falls. (b) Depth of best fit between alkenone and model temperature trend (red dots) and depth where nitrate concentration is $4 \mu \mathrm{mol} \mathrm{L}^{-1}$ (blue dots). (c) As (b), but for $\mathrm{Mg} / \mathrm{Ca}$-based temperature trends. The number of points may not be identical because of missing values or the values are out of range in the vertical. Crosses in indicate the record locations where the test of the regression residuals fails to show randomness.

over the course of the Holocene might cause a biased temperature reconstruction. Since, in our study, the alkenone- and $\mathrm{Mg} / \mathrm{Ca}$-based SST reconstructions cannot be reconciled with an annual mean temperature signal as simulated by the climate models, we further consider potential seasonal biases of the proxies. When considering local summer and local winter (Fig. 10a and b), temperature trends derived from alkenone and $\mathrm{Mg} / \mathrm{Ca}$ records show significant correlations between the alkenone proxy record and the climate simulation for the summer $(R=0.44, p<0.05)$ and the annual mean $(R=0.49, p<0.05)$. In the case of $\mathrm{Mg} / \mathrm{Ca}$, we observe negative significant correlations for the summer $(R=-0.56$, $p<0.05)$ and the annual mean $(R=-0.31, p>0.05)$. Considering local seasons does not decrease the disagreement between model temperature trends and alkenone SST trends. For $\mathrm{Mg} / \mathrm{Ca}$ we find an improvement for winter mean, but the correlation is weak and not significant $(R=0.17, p>0.05)$. This is likely caused by a regional dependency of the seasonal bias. However, even allowing a different seasonality for each core leaves a mismatch to the simulated trends for more than $50 \%$ of the alkenone cores and about $50 \%$ for $\mathrm{Mg} / \mathrm{Ca}$ cores (Fig. 6).

The degree of seasonal bias might be spatially dependent since the biogeographical properties of the ocean differ from one location to another (Prahl et al., 2010, and references therein). Lorenz et al. (2006) summarized previous studies, which suggested that in high latitudes the maximum production of coccolithophorids occurs in summer (Baumann et al., 1997, 2000), which supports the idea that alkenones record summer temperatures (Sikes et al., 1997; Leduc et al., 2010a; Prahl et al., 2010). Satellite data further supports the idea of summer-biased alkenone records (Iglesias-Rodriguez et al., 2002).

\subsection{Recorder system: regional seasonal biases}

It has been argued that high-latitude alkenone production may be light limited (Leduc et al., 2010a; Schneider et al., 2010) and therefore records the summer season, which may explain why alkenone-derived SST trends in the North Atlantic Ocean follow the Northern Hemisphere summer insolation (Lorenz et al., 2006). Indeed, we find a good agreement 

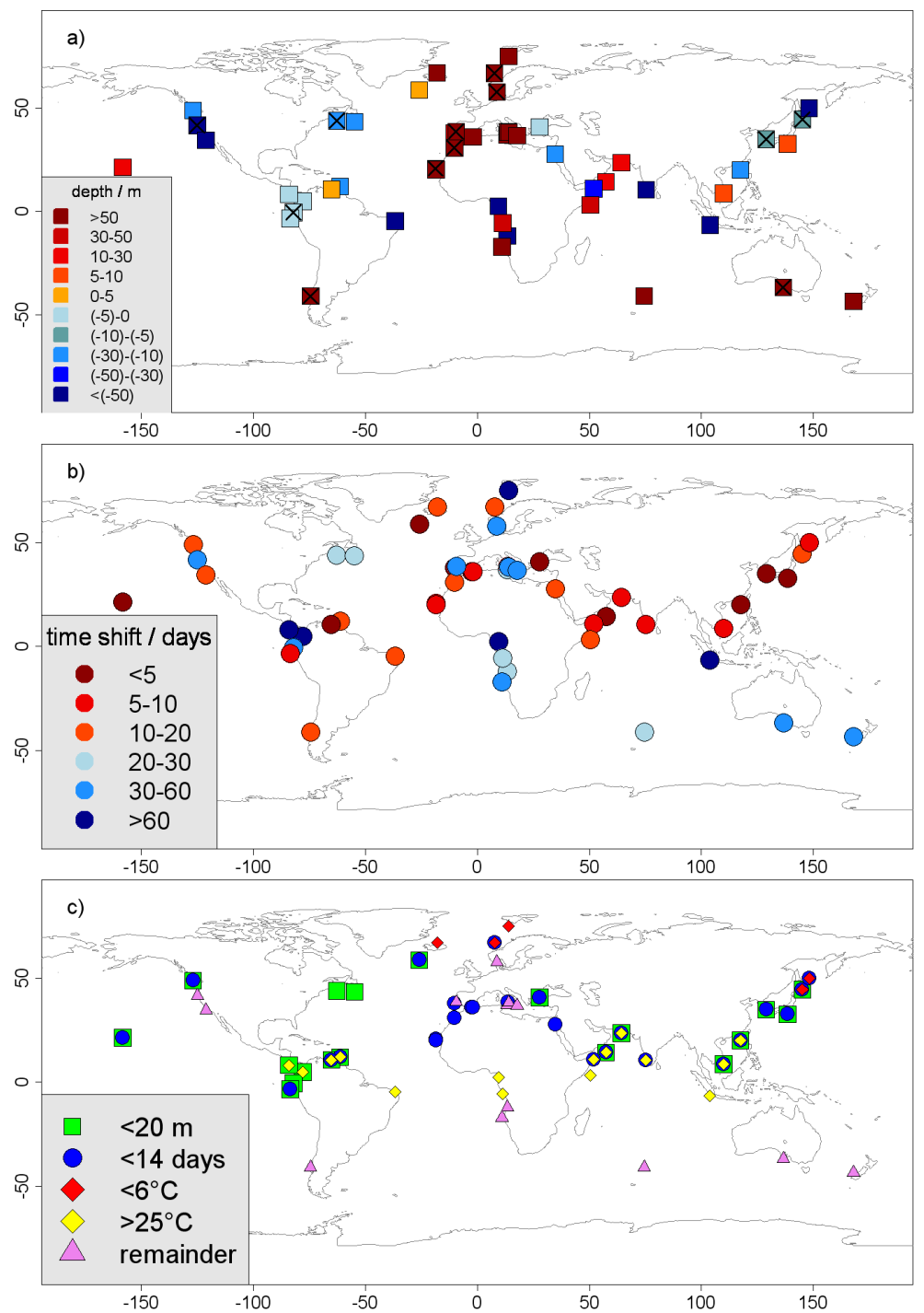

Fig. 12. (a) Vertical shift that is needed to minimize model-data disagreement. (b) Time shift that is needed to minimize model-data disagreement. (c) Global SST trends of the annual mean model output. The icons indicate the location of alkenone proxy records and the time or vertical shift that is needed to minimize the disagreement between the model simulation and data reconstruction. Diamonds are for cores where the calibration maximum causes problems. Triangles are used for reminder cores. Crosses in (a) indicate the record locations where the test of the regression residuals fails to show randomness.

between modelled summer temperatures and the proxy reconstruction for the North Atlantic Ocean (Fig. 10b), but we still observe a disagreement between the amplitudes of the trends. There is also a clear mismatch between modelled and reconstructed SST trends in the eastern and western Pacific Ocean (Fig. 10b). Alkenone SSTs in the southern high latitudes were proposed to be skewed toward summer as well (Sikes et al., 2002). Alkenone SSTs located in the southern mid- to high latitudes indicate a Holocene SST cooling which is reproduced by the modelled summer SST evolution, even though the magnitudes of SST changes are still larger in the proxy records (Fig. 10b).
Seasonality in phytoplankton production is generally less pronounced in tropical and subtropical regions (Jickells et al., 1996), and alkenone-derived SSTs from low-latitude sites are therefore more likely to be representative of temperatures close to the annual mean values (Müller and Fischer, 2001; Kienast et al., 2012). It also has been argued that at low latitudes alkenones might record a boreal winter signal when a decrease in the surface ocean stratification reduces SST and enhances primary productivity (Bijma et al., 2001; Leduc et al., 2010a). In our study, we find best agreement between reconstructed and annual mean temperatures in low latitudes (Fig. 5). We still have a considerable number of records $(\sim 52 \%)$ at low latitudes that agree best with either 

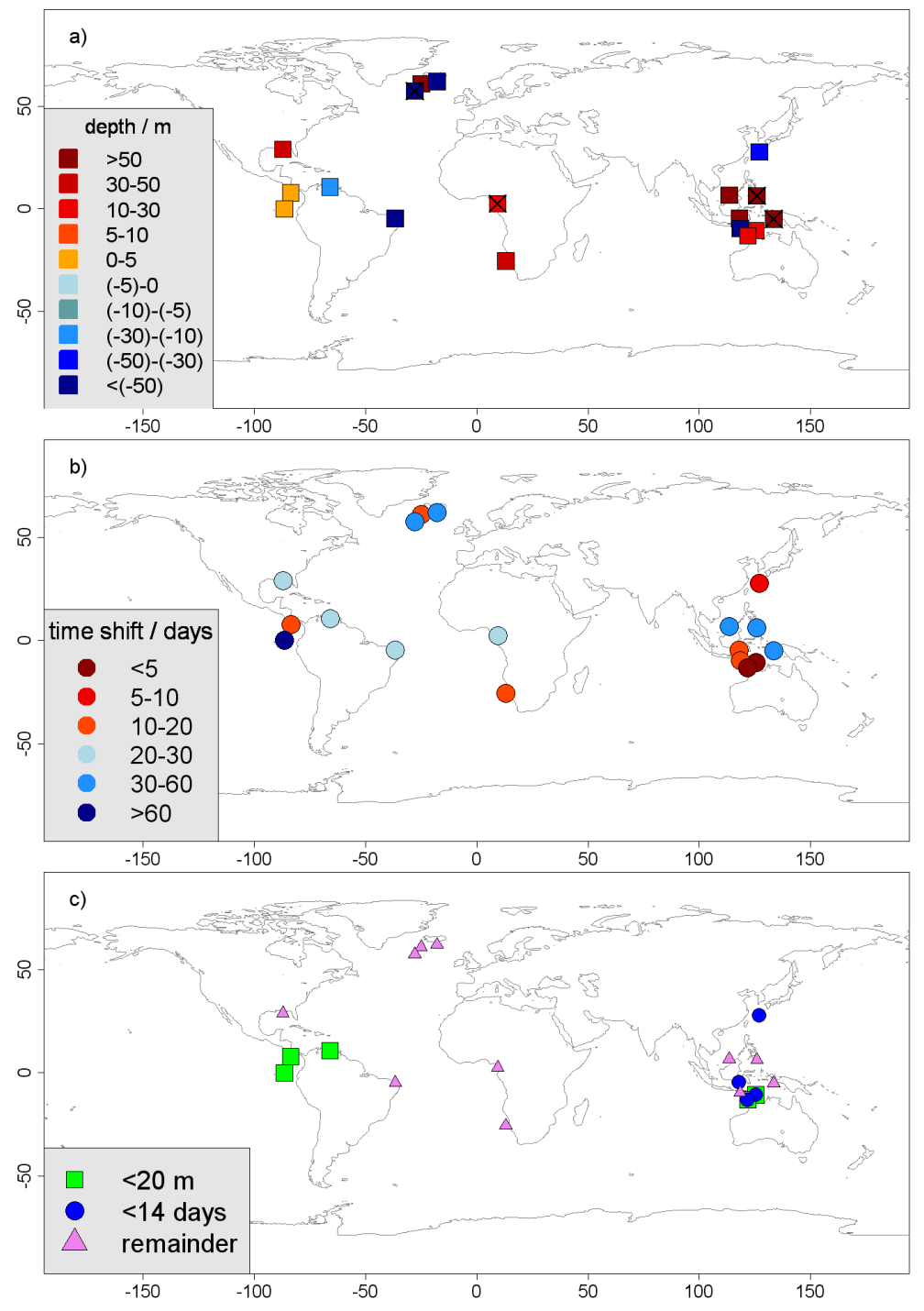

Fig. 13. (a), (b), and (c) as Fig. 12, but for $\mathrm{Mg} / \mathrm{Ca}$-based temperature trends.

local summer $(\sim 35 \%)$ or local winter $(17 \%)$, but the spatial patterns of these matches are featureless. In the eastern South Atlantic Ocean, only one record fits best to the mean annual SST while the nearby cores show a local summer signal. For $\mathrm{Mg} / \mathrm{Ca}$ in tropical regions, the large heterogeneity in $\mathrm{Mg} / \mathrm{Ca}$ and modelled SST trends does not allow us to draw any firm conclusion on where and how model and data disagree (Figs. 5-8).

Schneider et al. (2010) employed marine temperature proxies for a model-data SST comparison, using results from an AOGCM for three time slices $(9.5,6 \mathrm{kyr} \mathrm{BP}$ and PI). In their study, they made several assumptions on how proxy records might be seasonally biased by defining four different filters. They estimate which seasonal bias might be represented in a certain proxy record, and identify regions where proxy records are biased towards a specific season, by applying these filters to the simulated SST trend. Schneider et al. (2010) defined a seasonal index weighting that relies on the modern relationship between net primary production (NPP) and SSTs. We do not assume a constant PI relationship between NPP and SST and refrain from considering such a filter. Similar to our study, Schneider et al. (2010) found that the North Atlantic Ocean is mostly influenced by a local summer bias in alkenone-based SSTs, while records in the western Pacific Ocean preferably represent a winter signal. The correlation values between proxy records and filtered model simulations that Schneider et al. (2010) estimate are higher than those that we find, which might be attributed to the preselection of proxy records that Schneider et al. (2010) applied prior to the correlation estimation. 


\subsection{Recorder system: habitat depth}

In the same way, a change in the habitat depth of the SST carries over the Holocene could create deviations between proxy records and model simulations. Such changes in habitat depth and recording season could have been caused by changes in insolation over the Holocene or by related changes in the ocean temperature and nutrient distribution that the alkenone-producing organisms and the foraminifera are exposed to.

Comparing the reconstructed Holocene temperature trends at model levels in the upper $100 \mathrm{~m}$ does not remove the discrepancy between models and proxies. For $\mathrm{Mg} / \mathrm{Ca}$ ratios, the greatest number of records fit best with model trends at $10 \mathrm{~m}$ water depth $(\sim 32 \%$ of the records), and smaller proportions of $\mathrm{Mg} / \mathrm{Ca}$ ratios fit best with trends for depths greater than $10 \mathrm{~m}$ (Table 4). For alkenones, we find best agreement in the upper $10 \mathrm{~m}(\sim 34 \%)$, while the other $\sim 66 \%$ of the records best agree in deeper layers (Table 4). Thus, we find that the highest agreement between proxy-recorded and simulated temperature trends is in the most upper ocean layer. This is in agreement with results from Rosell-Melé et al. (1995), who compared core-top alkenone-derived SSTs from the surface sediments to SSTs from overlying waters for different depths and found best agreement of alkenone SSTs with temperature at the ocean surface.

Our calculations of seasonality and upper ocean stratification are based on model output. They do not provide any diagnostic on the real ecological behaviour of planktonic organisms. However, they do provide a mapping of oceanic regions where even small changes in the planktonic organisms' ecology can have large consequences on the reconstructed local SST trends. It reinforces the idea that alkenones and $\mathrm{Mg} / \mathrm{Ca}$ may be affected by ecological specificities (Leduc et al., 2010a).

\subsection{Recorder system: shifts in seasonal preferences and habitat depth}

Since neither seasonal nor habitat depth preferences of the proxy recorder can resolve the model data mismatch, we explore whether shifts in either depth habitat or growing season from the mid-Holocene to the present might cause the model-data disagreement. To explain the model-data mismatch by those mechanisms, summer sensitive proxyrecording species in the northern high latitudes would have to record summer temperatures in the mid-Holocene, and temperatures that are biased toward spring or autumn in the present-day climate. If the organisms changed their recording behaviour over the Holocene in such a way, this would increase a corrected proxy-based SST trend. Consequently, a corrected proxy-based SST trend would be in better agreement with the model simulations of the Holocene.

On the one hand it is questionable whether proxyrecording species really behave in such a way, as the organisms would likely try to keep their preferred ecological conditions by shifting their living seasons in a way that mitigates the changes in the climate (Mix, 1987). Fraile (2008) and Fraile et al. (2009) analysed the seasonality of the foraminifera species using a planktonic foraminifera model and showed that the organisms record a weaker temperature signal if a change in global temperature is applied. They performed a model sensitivity study by decreasing the global temperature by 2 and $6^{\circ} \mathrm{C}$, and found a shift in the maximum planktonic foraminifera abundance towards warmer seasons, which would decrease the temperature trend captured in $\mathrm{Mg} / \mathrm{Ca}$ records (Fraile et al., 2009).

On the other hand, planktonic organisms are subject to several limiting factors, e.g. temperature as well as lightand nutrient-availability. If those factors change in opposite directions, the organisms might change their living season without bypassing their basic ecological requirements. For example, food or nutrient availability might shift towards spring or autumn so that the living season might shift accordingly. To be able to explain such shifts, more studies using complex ecosystem models of the planktonic organisms need to be done, such as ecophysiological models reproducing the growth of planktonic foraminifera (Lombard et al., 2011).

It is not obvious which amplitude a seasonal shift realistically might have had during the Holocene. Our results show that indeed $48 \%$ of the alkenone records cannot be reconciled with the model simulation when considering a shift of less than 14 days over the last 6 kyr. For nearly all the records (47 out of 52), the mismatch between model and data can be removed by allowing a longer time shift of the recording season of up to 60 days (Fig. 12b). In the case of $\mathrm{Mg} / \mathrm{Ca}$, up to $\sim 21 \%$ of the records could be reconciled with the model simulation if we consider a potential shift in the recording season of less than 14 days (Fig. 13b and c), but only 1 out of 19 records would require a shift of more than 60 days.

We also find a latitudinal-dependent depth profile of alkenones which might be linked to the nitrate concentration (Fig. 11b). This suggests that the best fitting model depth indeed might depend on the location, which might reflect an influence of stratification on surface ocean biogeochemistry and stratification. For $\mathrm{Mg} / \mathrm{Ca}$ we do not detect a relationship (Fig. 11c), although we did not take into account speciesspecific ecological behaviour in our study. While the lowlatitude $\mathrm{Mg} / \mathrm{Ca}$ records derived from the symbiont-bearing foraminifer $G$. ruber require those records to be restricted to the euphotic zone, the mid- to high-latitude records derived from $G$. bulloides and N. pachyderma may integrate to some extent a subsurface signal.

If such a preference for a certain habitat depth changed with time, this would allow for another mechanism that might explain the mismatch between model simulation and proxy-reconstruction linked to planktonic organisms' migrations in the water column. Such a shift in living depth is supported by the indication that the detachment of coccoliths on 
coccolithophores plays a role in the regulation of buoyancy (Fritz and Balch, 1996). The non-detachment of the coccoliths would allow the alkenone-producing organisms to migrate by as much as $100 \mathrm{~m}$ in the euphotic zone in about 75 days (Fritz and Balch, 1996), facilitating access to the subsurface nutricline (Munk and Riley, 1952).

The vertical shift that might eliminate the disagreement between proxy recorder and model simulation can reconcile up to $37 \%$ of the records with the modelled SST trends if a vertical shift of less than $20 \mathrm{~m}$ is allowed. About $46 \%$ of the cores would require a shift of more than $50 \mathrm{~m}$ to be in agreement with modelled SSTs. Considering the annual cycle of the maximum alkenone concentration reported by Ternois et al. (1997), the possibility of a vertical shift of about $20 \mathrm{~m}$ seems to be a reasonable assumption. Therefore, a significant proportion of the proxy records may be reconciled with the model simulation by assuming a vertical shift of the alkenone-producing organisms' habitat depth. Yet, in our study shifts in seasonality seem to have greater potential to explain the model-proxy disagreement. It is possible that biases in the palaeothermometers may add further degrees of freedom to reconcile models and data. We however do not believe that those biases would be systematic enough to be responsible for the observation we made that models seem to underestimate Holocene SST trends as alkenone and $\mathrm{Mg} / \mathrm{Ca}$ records suggest.

\subsection{Climate models: coarse resolution}

Climate models are limited in their spatial resolution (computational constrains) and necessary approximations. Therefore, they cannot represent the full complexity of the earth system. The proxy records used in this study (and many others) are mostly located in coastal areas. These regions are typically not well represented by climate models due to their low resolution. Coastal areas may be especially sensitive to external forcing, since their thermal inertia may be lower than that of the open ocean due to a shallower thermocline and land-ocean interactions. Furthermore, the representation of mixed layer dynamics is probably important to improve climate simulations and their agreement with palaeoceanographic reconstructions.

In order to see the potential source of uncertainty in the models, we evaluate the temperature and mixed layer depth in the models by comparing them with the temperature and mixed layer depth of the ocean reanalysis data SODA covering 1958-2001 (Carton and Giese, 2008; Carton et al., 2005). The mixed layer depth of the model (HOPE-G) is calculated following the temperature criterion as described in Levitus (1982), which defines the mixed layer as the depth at which the temperature change from the surface temperature is $0.5^{\circ} \mathrm{C}$. The same method is used for calculating the mixed layer depths from the ocean reanalysis data. Before the calculation of the mixed layer depth, the observational data were vertically interpolated to the HOPE-G model depths.

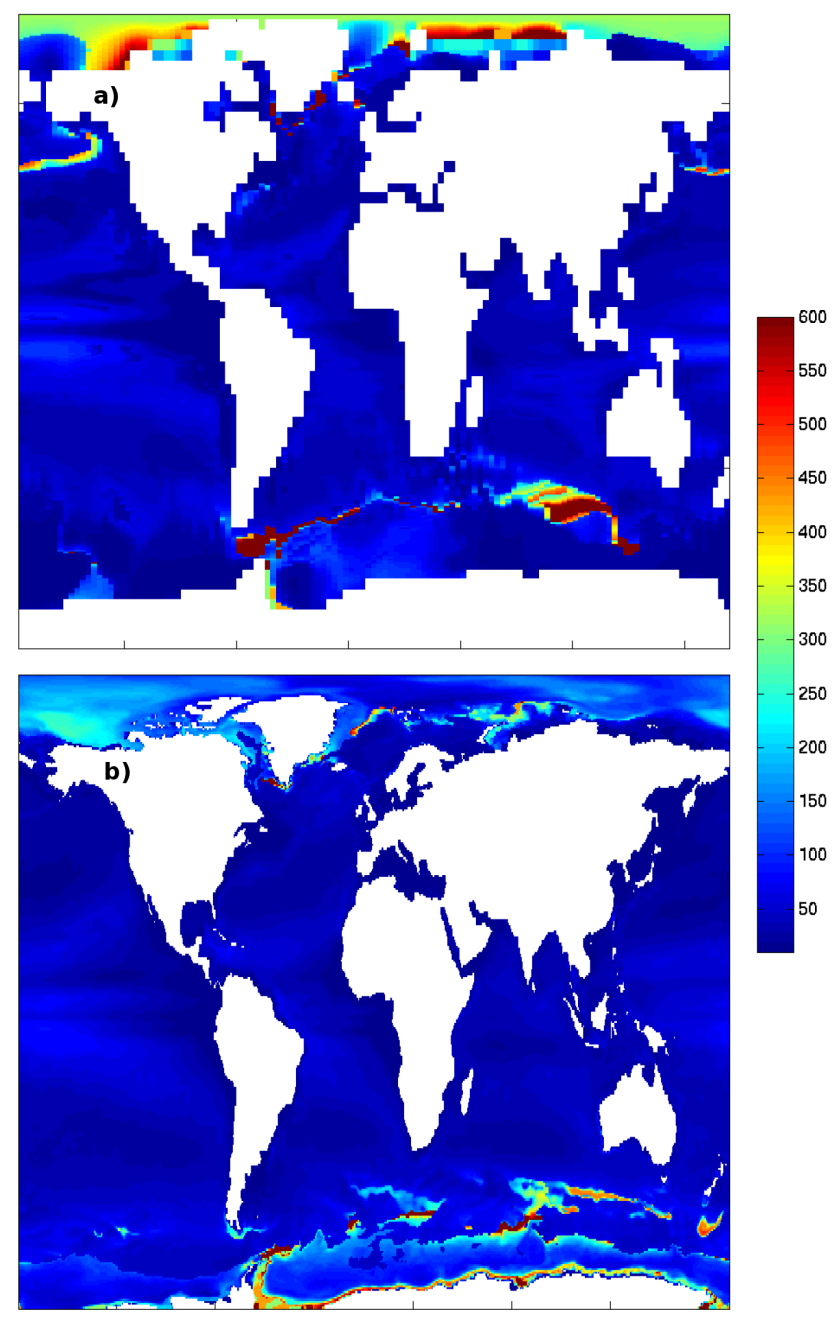

Fig. 14. Annual mean mixed layer depth in the ocean $(m)$ following the temperature criterion as described in Levitus (1982). (a) HOPEG, and (b) for the SODA dataset (Carton and Giese, 2008; Carton et al., 2005).

For the ECHO-G model, we used the mean of the last $50 \mathrm{yr}$ representing the latest Holocene. We see a similar large-scale pattern in the model and SODA (Fig. 14), but also deviations especially in the Southern Ocean where bounday and ice-shelf processes are not resolved. Finally, we calculate the SST bias between the ECHO-G, the PMIP2, and PMIP3 models for their pre-industrial climate and SODA (similar results are obtained when using other SST data, not shown). Figure 15 indicates a strong bias at high northern latitudes towards colder conditions, and a warm bias in the Southern Ocean and in major upwelling regions for the models (ECHO-G, PMIP2, and PMIP3 in the panels, respectively). We detect furthermore a strong systematic bias in the Gulf Stream fronts (Fig. 15). The temperature changes are clearly outside the range of decadal-to-centennial variability (Wei and Lohmann, 2012). It is beyond the scope of the present 

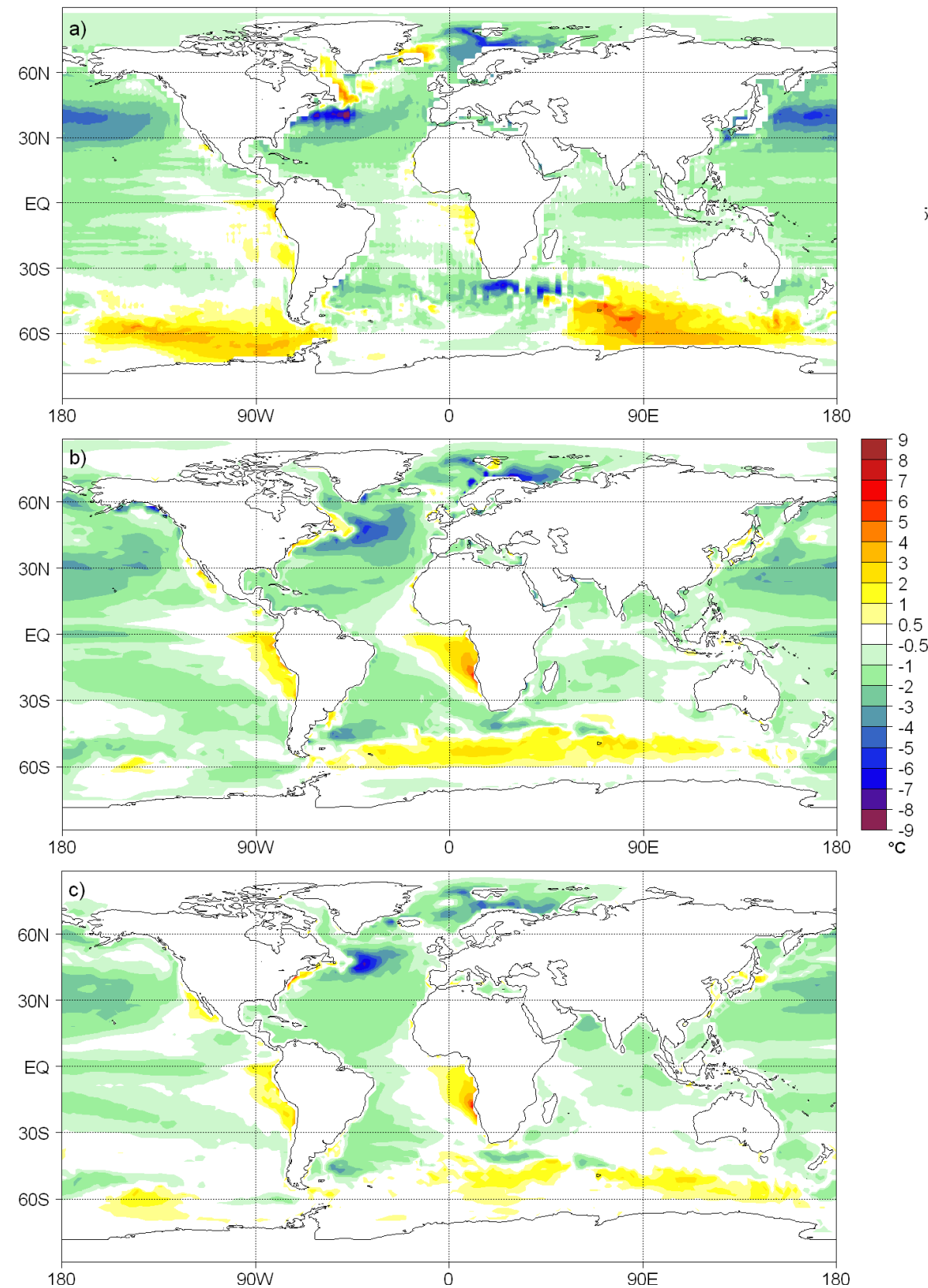

Fig. 15. Simulated annual mean SST anomalies for the preindustrial climate relative to SSTs in the ocean reanalysis data SODA (Carton and Giese, 2008; Carton et al., 2005). Calculated for ECHO-G (a), from the ensemble median mean of the models listed in PMIP2 (b) and PMIP3 (c).

paper to discuss the reasons for the systematic model deficiencies, but one can mention the uncertainty related to subgridscale oceanic mixing and the difficulty in resolving the frontal systems.

Other local feedbacks operating in upwelling systems might also complicate the SST model-data comparison, since local cooling can take place within regions where in general widespread warming is observed (Leduc et al., 2010b). In a similar way, mismatches can be due to difficulties in capturing changes in oceanic fronts in the models.

The similarity of the results when using the transient ECHO-G simulation and the ensemble of PMIP simulations shows that the deviation between proxy data and model simulations does not seem to be a problem of specific climate models, but seems to be a robust feature of Holocene climate simulations with global coupled climate models. One testable hypothesis is that proxy records can therefore 
correctly record local temperature trends that cannot be simulated by the models. A possible way to examine this effect can be through a new ocean model which has high resolution of up to $7 \mathrm{~km}$ in deep water formation areas and in coastal areas where a higher sensitivity to external forcing is expected (Scholz et al., 2013). A logical next step is the application of this model to the Holocene.

\subsection{Spatial representativeness of the data}

Palaeoclimate information gathered from model-data comparisons are difficult to be put into a context which goes beyond a description of observed model-data discrepancies, as both climate models and proxy reconstructions are imperfect and have very different characteristics. Proxy reconstructions are sparse and patchy, and can be affected by local processes and/or proxy specificities, which are not always considered in palaeoclimate reconstructions. Usually, palaeoclimatologists tend to obtain data in regions where sedimentation allows it and where the signal is clear. Therefore, it could be that the SST signals are overestimated due to the selection of the sites. Climate models have coarse spatial and temporal resolutions, but can resolve changes in climatic features with a global perspective and thus help in identifying the mechanisms of climate variations. Here, we discuss the large-scale pattern of the temperature evolution only. Spatially heterogenous patterns and regional dynamics provide an additional uncertainty for our data-model comparison. Furthermore, we cannot exclude that part of the signal is due to differential degradation of alkenones under contrasting bottom water oxygen conditions (Hoefs et al., 1998; Gong and Hollander, 1999). We will follow this hypothesis in a further study to examine if and how redox conditions during early organic matter diagenesis can also be determined.

Additional biases may also complicate the interpretation of $\mathrm{Mg} / \mathrm{Ca}$ and alkenone palaeothermometers. In particular, alkenones can be transported over long distances along with fine-grained particles (Ohkouchi et al., 2002), while $\mathrm{Mg} / \mathrm{Ca}$ may be impacted by dissolution (Tachikawa et al., 2008). Alkenone advection over long distances can invalidate those records as local SST indicators (Sicre et al., 2005). However, we expect that advection would in general tend to reduce the signal when propagating through different water masses smoothing the signal. It is therefore not likely that advection plays the dominant role for the large-scale reconstructed temperature signal based on alkenones.

As we cannot monitor the two above-mentioned processes for our database, we consider them as having not affected the Holocene SST records we analyse here. We however do expect those biases to have had an impact on the reconstructed SST trend in specific regions only and not as a whole. We note that in frontal systems and dynamically active regions, it can strongly affect the interpretation (e.g. Rühlemann and Butzin, 2006).

\subsection{Calibration of the proxy data}

In regional and global core-top calibrations, $U_{37}^{K^{\prime}}$ correlates best to the annual mean SST (Rosell-Melé et al., 1995; Herbert et al., 1998; Müller et al., 1998), but this finding could be limited to the spatial relationship and does not imply that $U_{37}^{K^{\prime}}$ individually record annual mean surface temperatures. Indeed, high-latitude core-top studies suggest that the alkenones are skewed toward summer temperatures (Sikes et al., 1997; Prahl et al., 2010). At low latitudes, it is also unclear whether alkenone-based SST estimates reflect mean annual SST or are skewed toward seasons during which temperatures are below the mean annual SST. A study of regional sediment traps has shown that low-latitude alkenones most likely record annual mean temperatures (Müller and Fischer, 2001) despite the fact that alkenone-producing coccolithophorids mostly thrive during winter to spring (Müller and Fischer, 2001; Cortés et al., 2001; Bijma et al., 2001), or more generally when nutrients are abundant (Baumann et al., 2000). A recent core-top study from the eastern equatorial Pacific Ocean seems to confirm this hypothesis (Kienast et al., 2012). Such observations may explain the mismatch between the SST calibration curves which are established from alkenone SST derived from sediment trap material (that best fit with ambient temperature through a non-linear calibration curve) and those which are established from core tops (that best fit with the mean annual SST overlying core tops through a linear calibration curve) (Conte et al., 2001, 2006). Conte et al. (2006) argued that such mismatch can at least partly be explained by seasonality and water depth of coccolithophorids, suggesting that ecological effects may somewhat be embedded in modern sedimentary material.

The uncertainties embedded in seasonal signals of $\mathrm{Mg} / \mathrm{Ca}-$ based SST data may be more readily identified since available SST records and calibrations are species specific (e.g. Anand et al., 2003). It means that refining $\mathrm{Mg} / \mathrm{Ca}$ interpretation in light of the foraminiferal seasonal preferences may theoretically be undertaken by field studies. Yet, seasonal preferences for a given species can also vary from site to site. For example, fluxes of the surface-dwelling planktonic foraminifer G. ruber, the species most represented in the updated version of the GHOST database, were found to be maximum during summer in the Panama Basin when surface waters are well stratified (Thunell et al., 1983), but during winter south of Java when upwelling occurs (Mohtadi et al., 2009). G. bulloides is, on the other hand, usually associated with upwelling events and tends to flourish whenever primary productivity increases since it needs abundant food to develop (e.g. Lombard et al., 2011).

\subsection{Model-data comparison: ecological requirements}

Model-data comparisons of Holocene temperature evolution induced by insolation changes have independently proposed that seasonality of coccolithophorid blooms can explain 
part of the reconstructed temperature signal at low latitudes (Lorenz et al., 2006; Schneider et al., 2010). However, beyond the firm limits of basic ecological requirements of planktonic organisms, there is still a lack of a conceptual model for explaining the season and water depth embedded in SST signal carriers that can globally explain how and where ecological optima are reached for a given foraminifera or coccolithophorid species. Our study goes beyond the work of Schneider et al. (2010) in that we quantify the amplitude of the biases that the proxy records might include. Additional to seasonal shifts of the recording season, we also include and quantify shifts in the habitat depth.

The dependence of the temperature record on the habitat depth has not been studied as much as seasonality. For the Mediterranean Sea, Bentaleb et al. (1999) suggested that alkenones are essentially synthesized at levels of highest primary production, and therefore may record a signal which integrates subsurface temperature where a chlorophyll maximum can develop seasonally. Another study from the Arabian Sea indeed demonstrated that alkenone-synthesizing coccolithophorids are several orders of magnitude more abundant at subsurface as compared to the surface (Andruleit et al., 2003). This vertical displacement is of course strictly restricted to the euphotic zone, which sets a lower firm limit on where alkenones are being synthesized. As for coccolithophorids, foraminifera are subject to changes in the depth habitat (see e.g. Fairbanks et al., 1982). Even though G. ruber and G. bulloides are both considered as surface ocean dwellers, only G. ruber must thrive in the euphotic zone to allow the photosynthesis of its symbiont-bearing organisms. Recent studies indeed suggest that the G. bulloides life cycle associated with gametogenesis involves calcification of its test within subsurface and may significantly affect its resulting $\mathrm{Mg} / \mathrm{Ca}$ value (Marr et al., 2011). In summary, it appears that potential changes in seasonality and upper water column structure, likely accompanying Holocene changes in ocean dynamics, provide two degrees of freedom which have the potential to explain the model-data mismatch and warrant further investigations.

\subsection{Forcing and internal variability}

Besides the insolation forcing, changes in greenhouse gases may play a role. However, the radiation effect due to $\mathrm{CO}_{2}$ is rather small and has a negligible influence on our results (not shown). Internal variability is expected to have a minor effect on the overall hemispheric temperature trends. However, it was concluded that part of the regional Holocene SST trend can be attributed to a pattern which resembles the Arctic Oscillation/North Atlantic Oscillation (Rimbu et al., 2003) and modulations of the Icelandic Low (Lohmann et al., 2005) showing opposite SST trends at one latitude. Such features are more difficult to assess in data and models because of their spatial heterogeneity and atmospheric dynamics.
One particular example of how complex the temperature trends in the North Pacific and Atlantic oceans are can be seen in Fig. 5. The opposite long-term SST trends between the northeastern Pacific and the northeastern Atlantic oceans during the Holocene has been attributed to inter-oceanic teleconnections during the Holocene related to Pacific-North Atlantic mode of variability (Kim et al., 2004). Such features have not been sufficiently tested in climate models on long timescales.

In the reconstructed SSTs, the millennial variability seems to be a robust feature through the Holocene (Rimbu et al., 2004). Wirtz et al. (2010) report furthermore on change in climate variability in the early to mid-Holocene which might influence regional temperature. However, Moros et al. (2004) report that, in the northern North Atlantic Ocean, planktonic $\delta^{18} \mathrm{O}$ shows a "rather flat early- to mid-Holocene and a marked increase in amplitude and decrease in mean values from about $4 \mathrm{kyr}$ BP", which could be linked with pronounced variations in the recorder system associated to different seasons and water depths. Large millennial variability in the data can mask the temperature trend, and in principle we cannot exclude other factors affecting the climate (Bond et al., 2001; Sundqvist et al., 2010). However, since we have taken the temperature trends only, we eliminated to a large extent the effect of millennial climate variability in our analysis (Figs. 1-4). Our analysis also shows that the estimates of the errors in the trends are larger when less data is available (Figs. 1-4). Interestingly, the long-term variability as documented in the data (Rimbu et al., 2004; Wirtz et al., 2010) is highly underestimated in multi-centennial to multimillennial model experiments. This variability, however, is beyond the scope of the present paper.

\subsection{Climate models: sensitivities to long-term changes}

Climate sensitivity is defined in the sense of Charney (1979), in which fast feedback processes are allowed to operate, but long-lived atmospheric gases, ice sheet area, land area and vegetation cover are considered as fixed forcings. Fast feedbacks include changes of water vapour, clouds, climatedriven aerosols, sea ice, and snow cover. Our inference that models do not capture the Holocene trends with respect to the amplitude found in the records could raise doubt about the correct representation of climate sensitivity in the climate models on long timescales.

Laepple and Lohmann (2009) calculated empirically the Holocene temperature evolution based on the analogy with the temperature response to the seasonal cycle. It turned out that the climate patterns resemble the large-scale features of the modelled Holocene trend (Lorenz and Lohmann, 2004), but the amplitude and regional changes associated with circulation changes are not well captured. By construction, longterm feedbacks are missing in such an approach. It is conceivable that present climate models neglect in a similar way long-term feedbacks amplifying the orbital forcing. The 
obliquity forcing provides a pattern of high-latitude cooling and low-latitude warming of annual mean temperature, while the precession response is only due to non-linearities (e.g. Laepple and Lohmann, 2009). Future sensitivity studies should identify potential missing positive feedbacks in the system. Indeed, experiments indicate potential positive feedback amplifying external forcing which is related to details in the representation of vegetation and albedo in the models (O'ishi and Abe-Ouchi, 2011). Warming in their models is due to direct amplification of warming over high-latitude land through increases in vegetation and reduced albedo during the summer and indirect amplification through sea-ice feedback in autumn and winter and snow albedo feedback in spring. Further model studies are necessary to examine whether the long-term climate sensitivity to orbital forcing has been underestimated.

We have to identify the model-data discrepancy in order to have a reliable estimate of simulated temperature trends of the past, their error bars, as well as an estimate of climate sensitivity on long timescales. It could be that current climate simulations underestimate the full range of climate warming on centennial to millennial timescales that might arise as a result of anthropogenic greenhouse gas emissions. The concept of climate sensitivity relies on the responses of slow feedback processes to forcing and subsequent involved feedback mechanisms (Hansen et al., 2007). It is therefore likely that the climate sensitivity (to greenhouse gas forcing and orbital forcing) is much greater than that due to fast feedbacks.

\section{Conclusions}

Our study shows that model simulations of the Holocene temperature evolution predict a large-scale high-latitude cooling and low-latitude warming, which is consistent with the temperature trends expected from insolation changes due to orbital forcing. The reconstructed SST trends by alkenones show a similar sign to the models, but about $75 \%$ of the trend variance in the sediment records remains unexplained.

The amplitudes of the simulated trends are significantly smaller than the reconstructed temperature trends by alkenones. This deviation persists for all considered models, even if we take into account seasonality and different water depths at which the recording organisms may have lived. This raises important questions as to whether climate models have fundamental deficiencies, and (or) whether our understanding of the proxy records still needs to be refined. We find best agreement between reconstruction and annual mean temperatures in low latitudes. The large spatial heterogeneity in $\mathrm{Mg} / \mathrm{Ca}$ and modelled SST trends does not allow us to draw any firm conclusion on where and how model and data disagree. Non-temperature effects upon the incorporation of $\mathrm{Mg} / \mathrm{Ca}$ in the foraminiferal shell (Arbuszewski et al., 2010), resuspension and redeposition of $U_{37}^{K^{\prime}}$ markers (Ohkouchi et al., 2002), and other possible post-depositional effects on
$\mathrm{Mg} / \mathrm{Ca}$ (Regenberg et al., 2006) or on $U_{37}^{K^{\prime}}$ (Hoefs et al., 1998; Gong and Hollander, 1999) could cause discrepancies.

We evaluate several mechanisms that can be responsible for the observed mismatch between the reconstructed and the modelled magnitude of the Holocene SST trends. These are systematic changes in the living season over the course of the Holocene and a varied habitat depth of the SST signal carriers. In many cases (up to $62 \%$ for alkenones and $42 \%$ for $\mathrm{Mg} / \mathrm{Ca}$ in our study), the mismatch between proxy and simulation may be removed if these mechanisms are considered. The amount of vertical shift of the recorder depth, or of the shift of the living season, that is needed to remove the model-proxy mismatch is within ranges that we consider realistic for climatic changes over the last $6 \mathrm{kyr}$.

We consider the model-data mismatch of Holocene temperature trends as being indicative of either model deficiencies or data particularities with respect to the planktonic organisms' ecology. When interpreting the proxy records, two assumptions regarding the stationary seasonality and habitat depth can be made. First, one could assume that the seasonality and the habitat depth of planktonic organisms did not change under varying climate conditions during the Holocene. Such an assumption is generally applied while interpreting palaeoreconstructions because it is difficult to assess how hydrographical changes occurred over contrasting seasons and habitat depths in the past. In such case, a good knowledge of the modern seasonality and living depth of coccolithophorids and foraminifera would be sufficient for the interpretation of the temperature record. Second, one could assume that living season and the habitat depth may have changed over time. In such a likely situation, the interpretation of the proxy record becomes more difficult. However, considering ecological limits of seasonality and habitat depth, the model simulations can be used to extract the range of possible proxy trends consistent with the simulated climate. Ecophysiological models accounting for planktonic foraminifera ecology capture most of the first-order seasonal and depth habitat preferences of the most commonly used species for $\mathrm{Mg} / \mathrm{Ca}$-based reconstructions (Fraile et al., 2009; Lombard et al., 2011). These models have further pointed out that any past climate change affecting surface ocean characteristics may alter foraminifera-derived SST climatic signals by modulating environmental characteristics for which planktonic foraminifera have optimal living conditions (Fraile et al., 2009; Bassinot et al., 2011). It is also conceivable that oceanic vertical mixing caused by atmospheric circulation and synoptic storms can affect the coccolith bloom period (Moros et al., 2004).

The underestimation of the Holocene SST trends by the models and/or the data overestimation is indeed a global and persistent feature that might be weakened, but not completely removed, if we consider proxies through their ecological prism. We show that differences in the magnitude of Holocene SST trends between model simulations on the one hand, and a global dataset of alkenone- and $\mathrm{Mg} / \mathrm{Ca}$-derived 
palaeotemperatures on the other hand, can be reconciled to some degree by considering shifts in seasonality and habitat depth - two parameters known to be relevant for understanding alkenone and $\mathrm{Mg} / \mathrm{Ca}$ palaeothermometry in the modern ocean.

This suggests that the discrepancy between our proxy database and the considered climate models is not only caused by a specific problem of the marine records used in this study, but a general problem that also occurs in other model-data comparisons (Brewer et al., 2007; Sundqvist et al., 2010; Zhang et al., 2010; O'ishi and Abe-Ouchi, 2011; Braconnot et al., 2012). At northern high latitudes, Sundqvist et al. (2010) report an annual mean $2^{\circ} \mathrm{C}$ cooling from the mid-Holocene to pre-industrial values, again larger than the model trends. A similar systematic deviation is also found for $\delta^{18} \mathrm{O}$-derived temperature trends from Greenland and Antarctic ice cores (Masson-Delmotte et al., 2006). They found that most models capture the correct sign of the reconstructed temperature change on Greenland, but underestimate its amplitude by a significant factor (e.g. Vinther et al., 2009). Recently, Braconnot et al. (2012) emphasized that the large-scale pattern in the Last Glacial Maximum and midHolocene simulation captures large parts of the temperature and precipitation changes over land, but it tends to underestimate the magnitude of regional changes.

It is therefore conceivable that the observed mismatch between modelled and reconstructed Holocene climate evolution is related to the lack of representativeness of long-term temperature trends in climate models. The models may not be sensitive enough with respect to insolation, may not be able to fully capture the natural range of climate variability, or might have regional biases linked to the fact that the proxy data records used in this study are located in coastal areas which are challenging to simulate with global climate models. Further studies are required to examine possible feedback mechanisms affecting the long-term climate sensitivity.

\section{Supplementary material related to this article is available online at: http://www.clim-past.net/9/1807/ 2013/cp-9-1807-2013-supplement.pdf.}

Acknowledgements. The work has been funded by the project "Evaluation of Eemian and Holocene Climate Variability: Synthesis of marine archives with climate modelling" within the priority programme Interdynamik of the German science foundation (DFG). We thank Stephan Lorenz for his help in preparation of the ECHO$G$ model data, the PMIP2 contributors for providing us their model output, and many contributors providing us with the proxy SST data (listed in Table 1 of this paper). Supplementary data for the model runs are available at http://dx.doi.org/10.1594/PANGAEA.815309. All authors contributed equally to the manuscript. We acknowledge the World Climate Research Programme's Working Group on Coupled Modelling, which is responsible for CMIP, and we thank the climate modelling groups of CMIP5 (listed in Table 2 of this paper) for producing and making available their model output. For CMIP the US Department of Energy's Program for Climate Model Diagnosis and Intercomparison provides coordinating support and led development of software infrastructure in partnership with the Global Organization for Earth System Science Portals. The referees and editor are acknowledged for their constructive suggestions to the manuscript.

Edited by: A. Paul

\section{References}

Anand, P., Elderfield, H., and Conte, M. H.: Calibration of $\mathrm{Mg} / \mathrm{Ca}$ thermometry in planktonic foraminifera from a sediment trap time series, Paleoceanography, 18, 1050, doi:10.1029/2002PA000846, 2003.

Andruleit, H., Stäger, S., Rogalla, U., and Čepek, P.: Living coccolithophores in the northern Arabian Sea: ecological tolerances and environmental control, Mar. Micropaleontol., 49, 157-181, 2003.

Arbuszewski, J., deMenocal, P., Kaplan, A., and Farmer, E. C.: On the fidelity of shell-derived $\delta^{18} \mathrm{O}$ seawater estimates, Earth Planet. Sc. Lett., 300, 185-196, doi:10.1016/j.epsl.2010.10.035, 2010.

Arz, H. W., Lamy, F., Pätzold, J., Müller, P. J., and Prins, M.: Mediterranean Moisture Soure for an Early-Holocene Humid Period in the Northern Red Sea, Science, 300, 118-121, 2003.

Bard, E., Rostek, F., and Sonzogni, C.: Inter-hemispheric synchrony of the last deglaciation inferred from alkenone palaeothermometry, Nature, 385, 707-710, 1997.

Barron, J. A., Heusser, L., Herbert, T., and Lyle, M.: High resolution climatic evolution of coastal Northern California during the past 16,000 years, Paleoceanography, 18, 1020, doi:10.1029/2002PA000768, 2003.

Barrows, T. T., Lehman, S. J., Fifield, L. K., and De Deckker, P.: Absence of cooling in New Zealand and the adjacent ocean during the Younger Dryas chronozone, Science, 318, 86-89, 2008.

Bartlein, P. J., Harrison, S. P., Brewer, S., Connor, S., Davis, B. A. S., Gajewski, K., Guiot, J., Harrison-Prentice, T. I., Henderson, A., Peyron, O., Prentice, I. C., Scholze, M., Seppä, H., Shuman, B., Sugita, S., Thompson, R. S., Viau, A. E., Williams, J., and $\mathrm{Wu}, \mathrm{H} .:$ Pollen-based continental climate reconstructions at 6 and $21 \mathrm{ka}$ : a global synthesis, Clim. Dynam., 37, 775-802, doi:10.1007/S00382-010-0904-1, 2011.

Bassinot, F. C., Marzin, C., Braconnot, P., Marti, O., Mathien-Blard, E., Lombard, F., and Bopp, L.: Holocene evolution of summer winds and marine productivity in the tropical Indian Ocean in response to insolation forcing: data-model comparison, Clim. Past, 7, 815-829, doi:10.5194/cp-7-815-2011, 2011.

Baumann, K.-H., Andruleit, H., Schröder-Ritzrau, A., and Samtleben, C.: Spatial and temporal dynamics of coccolithophore communites during non-production phases in the Norwegian-Greenland Sea, in: Contribution to the Micropaleontology and Paleoceanography of the Northern North Atlantic, edited by: Hass, H. C. and Kaminski, M. A., Grzybowski Found. Spec. Publ. 5, Krakow, 227-243, 1997. 
Baumann, K.-H., Andruleit, H. A., and Samtleben, C.: Coccolithophores in the Nordic seas: Comparison of living communities with surface sediment assemblages, Deep-Sea Res. Pt. II, 47, 1743-1772, 2000.

Bellouin, N., Boucher, O., Haywood, J., Johnson, C., Jones, A., Rae, J., and Woodward, S.: Improved representation of aerosols for HadGEM2, Technical Note 73, Meteorological Office Hadley Centre, Exeter, 2007.

Bendle, J. A. and Rosell-Melé, A.: High resolution alkenone sea surface temperature variability on the North Icelandic Shelf: implications for Nordic Seas paleoclimatic development during the Holocene, Holocene, 17, 19-24, 2007.

Bentaleb, I., Grimalt, J. O., Vidussi, F., Marty, J. C., Martin, V., Denis, M., Hatte, C., and Fontugne, M.: The C-37 alkenone record of seawater temperature during seasonal thermocline stratification, Mar. Chem., 64, 301-313, 1999.

Benway, H. M., Mix, A. C., Haley, B. A., and Klinkhammer, G. P.: Eastern Pacific warm pool paleosalinity and climate variability: 0-30 kyr, Paleoceanography, 21, PA3008, doi:10.1029/2005PA001208, 2006.

Berger, A. L.: Long-term variations of daily insolation and Quaternary climatic changes, J. Atmos. Sci., 35, 2362-2367, 1978.

Bijma, J., Altabet, M., Conte, M., Kinkel, H., Versteegh, G. J. M., Volkman, J. K., Wakeham, S. G., and Weaver, P. P.: Primary signal: Ecological and environmental factors - Report from Working Group 2, Geochem. Geophy. Geosy., 2, 1003, doi:10.1029/2000GC000051, 2001.

Bond, G., Kromer, B., Beer, J., Muscheler, R., Evans, M. N., Showers, W., Hoffmann, S., Bond, R. L., Hajdas, I., and Bonani, G.: Persistent solar influence on North Atlantic climate during the Holocene, Science, 294, 2130-2136, 2001.

Braconnot, P., Otto-Bliesner, B., Harrison, S., Joussaume, S., Peterchmitt, J.-Y., Abe-Ouchi, A., Crucifix, M., Driesschaert, E., Fichefet, Th., Hewitt, C. D., Kageyama, M., Kitoh, A., Laîné, A., Loutre, M.-F., Marti, O., Merkel, U., Ramstein, G., Valdes, P., Weber, S. L., Yu, Y., and Zhao, Y.: Results of PMIP2 coupled simulations of the Mid-Holocene and Last Glacial Maximum Part 1: experiments and large-scale features, Clim. Past, 3, 261277, doi:10.5194/cp-3-261-2007, 2007a.

Braconnot, P., Otto-Bliesner, B., Harrison, S., Joussaume, S., Peterchmitt, J.-Y., Abe-Ouchi, A., Crucifix, M., Driesschaert, E., Fichefet, Th., Hewitt, C. D., Kageyama, M., Kitoh, A., Loutre, M.-F., Marti, O., Merkel, U., Ramstein, G., Valdes, P., Weber, L., Yu, Y., and Zhao, Y.: Results of PMIP2 coupled simulations of the Mid-Holocene and Last Glacial Maximum Part 2: feedbacks with emphasis on the location of the ITCZ and mid- and high latitudes heat budget, Clim. Past, 3, 279-296, doi:10.5194/cp-3-279-2007, 2007b.

Braconnot, P., Harrison, S., Kageyama, M., Bartlein, P., MassonDelmotte, V., Abe-Ouchi, A., Otto-Bliesner, B., and Zhao, Y: Evaluation of climate models using palaeoclimatic data, Nat. Clim. Change, 2, 417-424, doi:10.1038/nclimate1456, 2012.

Bradley, R. S.: Paleoclimatology: Reconstructing Climates of the Quaternary, Academic Press, San Diego, 610 pp., 1999.

Brassell, S. C., Eglinton, G., Marlowe, I. T., Pflaumann, U., and Sarnthein, M.: Molecular stratigraphy: A new tool for climatic assessment, Nature, 320, 129-133, 1986.
Brewer, S., Guiot, J., and Torre, F.: Mid-Holocene climate change in Europe: a data-model comparison, Clim. Past, 3, 499-512, doi:10.5194/cp-3-499-2007, 2007.

Cacho, I., Grimalt, J. O., Pelejero, C., Canals, M., Sierro, F. J., Flores, J. A., and Shackleton, N. J.: Dansgaard-Oeschger and Heinrich event imprints in Alboran Sea paleotemperatures, Paleoceanography, 14, 698-705, 1999.

Cacho, I., Grimalt, J. O., Canals, M., Sbaffi, L., Schackleton, N. J., Shonfeld, J., and Zahn, R.: Variability of the Western Mediterranean sea surface temperatures during the last 25000 years and its connection with the northern hemisphere climatic changes, Paleoceanography, 16, 40-52, 2001.

Calvo, E., Grimalt, J., and Jansen, E.: High resolution UK37 sea surface temperature reconstruction in the Norwegian Sea during the Holocene, Quaternary Sci. Rev., 21, 1385-1394, 2002.

Calvo, E., Pelejero, C., De Deckker, P., and Logan, G. A.: Antarctic deglacial pattern in a $30 \mathrm{kyr}$ record of sea surface temperature offshore South Australia, Geophys. Res. Lett., 34, L13707, doi:10.1029/2007GL029937, 2007.

Came, R. E, Oppo, D. W., and McManus, J. F.: Amplitude and timing of temperature and salinity variability in the subpolar North Atlantic over the past 10 k.y., Geology, 35, 315-318, 2007.

Carton, J. A. and Giese, B. S. : A Reanalysis of Ocean Climate Using Simple Ocean Data Assimilation (SODA), Mon. Weather Rev., 136, 2999-3017, 2008.

Carton, J. A., Giese, B. S., and Grodsky, S. A.: Sea level rise and the warming of the oceans in the SODA ocean reanalysis, J. Geophys. Res., 110, C09006, doi:10.1029/2004JC002817, 2005.

Charney, J.: Carbon Dioxide and Climate: A Scientific Assessment, 33, National Academy Press, Washington, D.C., 1979.

Collier, M. A., Jeffrey, S. J., Rotstayn, L. D., Wong, K. K., Dravitzki, S. M., Moseneder, C., Hamalainen, C., Syktus, J. I., Suppiah, R., Antony, J., El Zein, A., and Artif, M.: The CSIROMk3.6.0 Atmosphere-Ocean GCM: participation in CMIP5 and data publication, International Congress on Modelling and Simulation - MODSIM 2011, Perth, 2011.

Collins, W. J., Bellouin, N., Doutriaux-Boucher, M., Gedney, N., Hinton, T., Jones, C. D., Liddicoat, S., Martin, G., O’Connor, F., Rae, J., Senior, C., Totterdell, I., and Woodward, S.: Evaluation of the HadGEM2 model, Technical Note 74, Meteorological Office Hadley Centre, Exeter, 2008.

Conkright, M. E. and Boyer, T. P.: World Ocean Atlas 2001: Objective Analyses, Data Statistics, and Figures, CD-ROM Documentation, National Oceanographic Data Center, Silver Spring, MD, 2002.

Conte, M. H., Thompson, A., Lesley, D., and Harris, R. P.: Genetic and physiological influences on the alkenone/alkenoate versus growth temperature relationship in Emiliania huxleyi and Gephyrocapsa oceanica, Geochim. Cosmochim. Acta, 62, 51-68, 1998.

Conte, M. H., Weber, J. C., King, L. L., and Wakeham, S. G.: The alkenone temperature signal in western North Atlantic surface waters, Geochim. Cosmochim. Acta, 65, 4275-4287, 2001.

Conte, M. H., Sicre, M.-A., Rühlemann, C., Weber, J. C., Schulte, S., Schulz-Bull, D., and Blanz, T.: Global temperature calibration of the alkenone unsaturation index $\left(U_{37}^{K^{\prime}}\right)$ in surface waters and comparison with surface sediments, Geochem. Geophy. Geosy., 7, Q02005, doi:10.1029/2005GC001054, 2006. 
Cortés, M. Y., Bollmann, J., and Thierstein, H. R.: Coccolithophore ecology at the HOT station ALOHA, Hawaii, Deep-sea Res. Pt. II, 48, 1957-1981, 2001.

Davis, B. and Brewer, S.: Orbital forcing and role of the latitudinal insolation/temperature gradient, Clim. Dynam., 32, 143-165, 2009.

deMenocal, P., Ortiz, J., Guilderson, T., Adkins, J., Sarnthein, M., Baker, L., and Yaarusinsky, M.: Abrupt onset and termination of the African Humid Period: rapid climate responses to gradual insolation forcing, Quaternary Sci. Rev., 19, 347-361, 2000.

Deuser, W. G. and Ross, E. H.: Seasonally abundant planktonic foraminifera of the Sargasso Sea: Succession, deep-water fluxes, isotopic composition, and paleoceanographic implication, J. Foramin. Res., 19, 268-293, 1989.

Dufresne, J.-L., Foujols, M.-A., Denvil, S., Caubel, A., Marti, O., Aumont, O., Balkanski, Y., Bekki, S., Bellenger, H., Benshila, R., Bony, S., Bopp, L., Braconnot, P., Brockmann, P., Cadule, P., Cheruy, F., Codron, F., Cozic, A., Cugnet, D., de Noblet, N., Duvel, J.-P., Ethé, C., Fairhead, L., Fichefet, T., Flavoni, S., Friedlingstein, P., Grandpeix, J.-Y., Guez, L., Guilyardi, E., Hauglustaine, D., Hourdin, F., Idelkadi, A., Ghattas, J., Joussaume, S., Kageyama, M., Krinner, G., Labetoulle, S., Lahellec, A., Lefebvre, M.-P., Lefevre, F., Levy, C., Li, Z. X., Lloyd, J., Lott, F., Madec, G., Mancip, M., Marchand, M., Masson, S., Meurdesoif, Y., Mignot, J., Musat, I., Parouty, S., Polcher, J., Rio, C., Schulz, M., Swingedouw, D., Szopa, S., Talandier, C., Terray, P., and Viovy, N.: Climate change projections using the IPSL-CM5 Earth System Model: from CMIP3 to CMIP5, Clim. Dynam., 40, 2123-2165, doi:10.1007/s00382-012-1636-1, 2013.

Emeis, K.-C., Struck, U., Schulz, H.-M., Rosenberg, R., Bernasconi, S., Erlenkeuser, H., Sakamoto, T., and MartinezRuiz, F.: Temperature and salinity variations of Mediterranean Sea surface waters over the last 16,000 years from records of planktonic stable oxygen isotopes and alkenone unsaturation ratios, Palaeogeogr. Palaeocl., 158, 259-280, 2000.

Emeis, K.-C., Struck, U., Blanz, T., Kohly, A., and Voß, M.: Salinity changes in the central Baltic Sea (NW Europe) over the last 10000 years, Holocene, 13, 411-421, 2003.

Emeis, K.-C. and Dawson A.: Holocene paleoclimate records over Europe and the North-Atlantic, Holocene, 13, 305-309, 2003.

Fairbanks, R. G., Sverdlove, M., Free, R., Wiebe, P. H., and Bé, A. W. H.: Vertical-distribution and isotopic fractionation of living planktonic-foraminifera from the Panama Basin, Nature, 298, 841-844, doi:10.1038/298841a0, 1982.

Fallet, U., Brummer, G. J., Zinke, J., Vogels, S., and Ridderinkhof, H.: Contrasting seasonal fluxes of planktonic foraminifera and impacts on paleothermometry in the Mozambique Channel upstream of the Agulhas Current, Paleoceanography, 25, A4223, doi:10.1029/2010PA001942, 2010.

Farmer, E. C., de Menocal, P. B., and Marchitto, T. M.: Holocene and deglacial ocean temperature variability in the Benguela upwelling region: implications for lowlatitude atmospheric circulation, Paleoceanography, 20, PA2018, doi:10.1029/2004PA001049, 2005.

Farmer, E. J., Chapman, M. R., and Andrews, J. E.: Centennial-scale Holocene North Atlantic surface temperatures from $\mathrm{Mg} / \mathrm{Ca}$ ratios in Globigerina bulloides, Geochem. Geophy. Geosy., 9, Q12029, doi:10.1029/2008GC002199, 2008.
Felis, T., Lohmann, G., Kuhnert, H., Lorenz, S., Scholz, D., Pätzold, J., Al-Rousan, S. A., and Al-Moghrabi, S. M.: Increased seasonality in Middle East temperatures during the last interglacial period, Nature, 429, 164-168, 2004.

Fraile, I.: Modeling the spatial and temporal distribution of planktonic foraminifera, Ph.D., University of Bremen, Bremen, Germany, 2008.

Fraile, I., Schulz, M., Mulitza, S., Merkel, U., Prange, M., and Paul, A.: Modeling the seasonal distribution of planktonic foraminifera during the Last Glacial Maximum, Paleoceanography, 24, PA2216, doi:10.1029/2008PA001686, 2009.

Fritz, J. J. and Balch, W. M.: A light-limited continuous culture study of Emiliania huxleyi: determination of coccolith detachment and its relevance to cell sinking, J. Exp. Mar. Biol. Ecol., 207, 127-147, 1996.

Gent, P. R., Danabasoglu, G., Donner, L. J., Holland, M. M., Hunke, E. C., Jayne, S. R., Lawrence, D. M., Neale, R. B., Rasch, P. J., Vertenstein, M., Worley, P. H., Yang, Z.-L., and Zhang, M.: The Community Climate System Model Version 4, J. Climate, 24, 4973-4991, 2011.

Giorgetta, M. A., Jungclaus, J., Reick, C., Stevens, B., Marotzke, J., Claussen, M., Roeckner, E., Mauritsen, T., Crueger, T., Schmidt, H., Manzini, E., Esch, M., Rast, S., Kinne, S., Zhang, K., Kornblueh, L., Haak, H., Segschneider, J., Six, K., Raddatz, T., Gayler, V., Schnur, R., Legutke, S., Widmann, H., and Glushak, K.: Climate variability and climate change in MPIESM CMIP5 simulations, submitted, 2012.

Gong, C. and Hollander, D. J.: Evidence for differential degradation of alkenones under contrasting bottom water oxygen conditions: Implication for paleotemperature reconstruction, Geochim. Cosmochim. Acta, 63, 405-411, 1999.

Gordon, C., Cooper, C., Senior, C. A., Banks, H., Gregory, J. M., Johns, T. C., Mitchell, J. F. B., and Wood, R. A.: The simulation of SST, sea ice extents and ocean heat transports in a version of the Hadley Centre coupled model without flux adjustments, Clim. Dynam., 16, 147-168, 2000.

Greaves, M., Caillon, N., Rebaubier, H., Bartoli, G., Bohaty, S., Cacho, I., Clarke, L., Cooper, M., Daunt, C., Delaney, M., deMenocal, P., Dutton, A., Eggins, S., Elderfield, H., GarbeSchoenberg, D., Goddard, E., Green, D., Groeneveld, J., Hastings, D., Hathorne, E., Kimoto, K., Klinkhammer, G., Labeyrie, L., Lea, D. W., Marchitto, T., Martínez-Botí, M. A., Mortyn, P. G., Ni, Y., Nuernberg, D., Paradis, G., Pena, L., Quinn, T., Rosenthal, Y., Russell, A., Sagawa, T., Sosdian, S., Stott, L., Tachikawa, K., Tappa, E., Thunell, R., and Wilson, P. A.: Interlaboratory comparison study of calibration standards for foraminiferal $\mathrm{Mg} / \mathrm{Ca}$ thermometry, Geochem. Geophy. Geosy., 9, Q08010, doi:10.1029/2008GC001974, 2008.

Guiot, J., Boreux, J. J., Braconnot, P., Torre, F., and PMIP participants: Data-model comparison using fuzzy logic in paleoclimatology, Clim. Dynam., 15, 569-581, 1999.

Hansen, J.: Climate change and trace gases, Philos. T. Roy. Soc. Lond. A, 365, 1925-1954, 2007.

Harada, N., Ahagon, N., Sakamoto, T., Uchida, M., Ikehara, M., and Shibata, Y.: Rapid flucatuation of alkenone temperature in the southwestern Okhotsk Sea during the past $120 \mathrm{ky}$, Global Planet. Change, 53, 29-46, 2006. 
Herbert, T. D. and Schuffert, J. D.: Alkenone unsaturation estimates of sea-surface temperatures at site 1002 over a full glacial cycle, Proc. Ocean Drill. Program, Sci. Results, 165, 239-247, 2000.

Herbert, T. D., Schuffert, J. D., Thomas, D., Lange, C., Weinheimer, A., Peleo-Alampay, A., and Herguera, J.-C.: Depth and seasonality of alkenone production along the California margin inferred from a core top transect, Paleoceanography, 13, 263-271, 1998.

Hoefs, M. J. L., Versteegh, G. J. M., Rijpstra, W. I. C., de Leeuw, J. W., and Sinnighe Damste, J. S.: Postdepositional oxic degradation of alkenones: Implications for the measurement of palaeo sea surface temperatures, Paleoceanography, 13, 42-49, 1998.

Iglesias-Rodriguez, M. D., Brown, C. W., Doney, S. C., Kleypas, J., Kolber, D., Kolber, Z., Hayes, P. K., and Falkowski, P. G.: Representing key phytoplankton functional groups in ocean carbon cycle models: coccolithophorids, Global Biogeochem. Cy., 16, 1100, doi:10.1029/2001GB001454, 2002.

Jacob, R., Schafer, C., Foster, I., Tobis, M., and Anderson, J.: Computational Design and Performance of the Fast Ocean Atmosphere Model, Version One, in: Proc. 2001 International Conference on Computational Science, edited by: Alexandrov, V. N., Dongarra, J. J., and Tan, C. J. K., Springer-Verlag, Heidelberg, 175-184, 2001.

Jansen, E., Overpeck, J., Briffa, K. R., Duplessy, J.-C., Joos, F., Masson-Delmotte, V., Olago, D., Otto-Bliesner, B., Peltier, W. R., Rahmstorf, S., Ramesh, R., Raynaud, D., Rind, D., Solomina, O., Villalba, R., and Zhang, D.: Palaeoclimate, in: Climate Change 2007: The Physical Science Basis, Contribution of Working Group I to the Fourth Assessment Report of the Intergovernmental Panel on Climate Change, edited by: Solomon, S., Qin, D., Manning, M., Chen, Z., Marquis, M., Averyt, K. B., Tignor, M., and Miller, H. L., Cambridge University Press, Cambridge, UK and New York, NY, USA, 2007.

Jickells, T. D., Newton, P. P., King, P., Lampitt, R. S., and Boutle, C. A.: Comparison of sediment trap records of particle fluxes from 19 to $48^{\circ} \mathrm{N}$ in the northeast Atlantic and their relation to surface water productivity, Deep-Sea Res. Pt. I, 48, 971-986, 1996.

Jungclaus, J. H., Keenlyside, N., Botzet, M., Haak, H., Luo, J.J., Latif, M., Marotzke, J., Mikolajewicz, U., and Roeckner, E.: Ocean Circulation and Tropical Variability in the Coupled Model ECHAM5/MPI-OM, J. Climate, 19, 3952-3972, doi:10.1175/JCLI3827.1, 2006.

K-1 Model Developers: K-1 coupled GCM (MIROC description) 1, Tokio, 34 pp., 2004.

Kaiser, J., Lamy, F., and Hebbeln, D.: A 70-kyr sea surface temperature record off southern Chile (Ocean Drilling Program Site 1233), Paleoceanography, 20, PA4009, doi:10.1029/2004PA001146, 2005.

Kennett, J. P., Roark, E. B., Cannariato, K. G., Ingram, B. L., and Tada, R.: Late Quaternary paleoclimatic and radiocarbon chronology, Hole 1017E, southern California Margin. Ocean Drill. Program, Sci. Results, 167, 249-254, doi:10.1029/2005PA001146, 2000.

Kienast, M., MacIntyre, G., Dubois, N., Higginson, S., Normandeau, C., Chazen, C. R., and Herbert, T. D.: Alkenone unsaturation in surface sediments from the eastern equatorial $\mathrm{Pa}-$ cific: Implications for SST reconstructions, Paleoceanography, 27, PA11210, doi:10.1029/2011PA002254, 2012.
Kienast, S. S. and McKay, J. L.: Sea surface temperature in the subarctic Northeast Pacific reflect millennial-scale Climate Oscillations during the last 16 kyrs, Geophy. Res. Lett., 28, 1563-1566, 2001.

Kim, J.-H. and Schneider, R. R.: GHOST global database for alkenone-derived Holocene sea-surface temperature records, http://www.pangaea.de/Projects/GHOST/Holocene (last access: 30 July 2013), 2004.

Kim, J.-H., Schneider, R. R., Müller, P. J., and Wefer, G.: Interhemispheric comparison of deglacial sea-surface temperature patterns in Atlantic eastern boundary currents, Earth Planet. Sc. Lett., 194, 383-393, 2002.

Kim, J.-H., Schneider, R. R., Mulitza, S., and Müller, P. J.: Reconstruction of SE trade wind intensity based on sea-surface temperature gradients in the SE Atlantic over the last $25 \mathrm{kyr}$, Geophys. Res. Lett., 30, 2144, doi:10.1029/2003GL017557, 2003.

Kim, J.-H., Rimbu, N., Lorenz, S. J., Lohmann, G., Nam, S.-I., Schouten, S., Rühlemann, C., and Schneider, R. R.: North Pacific and North Atlantic seasurface temperature variability during the Holocene, Quaternary Sci. Rev., 23, 2141-2154, 2004.

Kim, J.-H., Meggers, H., Rimbu, N., Lohmann, G., Freudenthal, T., Müller, P. J., and Schneider, R. R.: Impact of the North Atlantic gyre circulation on Holocene climate off Northwest Africa, Geology, 35, 387-390, 2007.

Köhler, P., Bintanja, R., Fischer, H., Joos, F., Knutti, R., Lohmann, G., and Masson-Delmotte, V.: What caused Earth's temperature variations during the last 800,000 years? Data-based evidence on radiative forcing and constraints on climate sensitivity, Quaternary Sci. Rev., 29, 129-145, doi:10.1016/j.quascirev.2009.09.026, 2010.

Koutavas, A. and Sachs, J.: Northern timing of deglaciation in the eastern equatorial Pacific from alkenone paleothermometry, Paleoceanography, 23, PA4205, doi:10.1029/2008PA001593, 2008.

Laepple, T. and Lohmann, G.: The seasonal cycle as template for climate variability on astronomical time scales, Paleoceanography, 24, PA4201, doi:10.1029/2008PA001674, 2009.

Lamy, F., Ruehlemann, C., Hebbeln, D., and Wefer, G.: High- and low-latitude climate control on the position of the southern PeruChile Current during the Holocene, Paleoceanography, 17, 1028, doi:10.1029/2001PA000727, 2002.

Lamy, F., Kaiser, J., Ninnemann, U., Hebbeln, D., Arz, H. W., and Stoner, J.: Antarctic Timing of Surface Water Changes off Chile and Patagonian Ice Sheet Response, Science, 304, 1959-1962, 2004.

Lamy, F., Kaiser, J., Arz, H. W., Hebbeln, D., Ninnmeann, U., Timm, O., Timmermann, A., and Toggweiler, J. R.: Modulation of the bipolar seesaw in the Southeast Pacific during Termination 1, Earth Planet. Sc. Lett., 259, 400-413, doi:10.1016/j.eps1.2007.04.040, 2007.

Lea, D. W., Pak, D. K., Peterson, L. C., and Hughen, K. A.: Synchroneity of tropical and high-latitude Atlantic temperatures over the last glacial termination, Science, 301, 1361-1364, 2003.

Leduc, G., Vidal, L., Tachikawa, K., Rostek, F., Sonzogni, C., Beaufort, L., and Bard, E.: Moisture transport across Central America as a positive feedback on abrupt climatic changes, Nature, 445, 908-911, 2007. 
Leduc, G., Schneider, R., Kim, J.-H., and Lohmann, G.: Holocene and Eemian sea surface temperature trends as revealed by alkenone and $\mathrm{Mg} / \mathrm{Ca}$ Paleothermometry, Quaternary Sci. Rev., 29, 989-1004, 2010a.

Leduc, G., Herbert, C., Blanz, T., Martinez, P., and Schneider, R.: Contrasting evolution of Sea Surface Temperature in the Benguela upwelling system under natural and anthropogenic climate forcings, Geophys. Res. Lett., 37, L20705, doi:10.1029/2010GL044353, 2010b.

Lee, K., Slowey, N., and Herbert, T.: Glacial sea surface temperatures in the Subtropical North Pacific: a comparison of $U_{37}^{K^{\prime}}$, $\delta^{18} \mathrm{O}$, and foraminiferal assemblage temperature estimates, Paleoceanography, 16, 268-279, 2001.

Legutke, S. and Voss, R.: The Hamburg atmosphere-ocean coupled circulation model ECHO-G, Technical Report 18, Deutsches Klimarechenzentrum, Hamburg, 1999.

Levi, C., Labeyrie, L., Bassinot, F., Guichard, F., Cortijo, E., Waelbroeck, C., Caillon, N., Duprat, J., de Garidel-Thoron, T., and Elderfield, H.: Low-latitude hydrological cycle and rapid climate changes during the last deglaciation, Geochem. Geophy. Geosy., 8, Q05N12, doi:10.1029/2006GC001514, 2007.

Levitus, S.: Climatological Atlas of the World Ocean, NOAA Professional Paper 13, US Department of Commerce, Silver Spring, MD, 1982.

Lohmann, G. and Lorenz, S. J.: Orbital forcing on atmospheric dynamics during the last interglacial and glacial inception, in Book on 'The climate of past interglacials', Series: Developments in Quaternary Science 7, edited by: Sirocko, F., Claussen, M., Sanchez-Goni, M. F., and Litt, T., Elsevier Series "Development in Paleoenvironmental Research", Elsevier, Amsterdam, 527-546, 2007.

Lohmann, G. and Wiltshire, K. H.: Winter atmospheric circulation signature for the timing of the spring bloom of diatoms in the North Sea, Mar. Biol., 159, 2573-2581, doi:10.1007/s00227012-1993-7, 2012.

Lohmann, G., Lorenz, S. J., and Prange, M.: Northern high-latitude climate changes during the Holocene as simulated by circulation models, in: The Nordic Seas: An Integrated Perspective, edited by: Drange, H., Dokken, T., Furevik, T., Gerdes, R., and Berger, W., Geophysical Monograph 158, American Geophysical Union, Washington, D.C., 273-288, doi:10.1029/158GM18, 2005.

Lombard, F., Labeyrie, L., Michel, E., Bopp, L., Cortijo, E., Retailleau, S., Howa, H., and Jorissen, F.: Modelling planktic foraminifer growth and distribution using an ecophysiological multi-species approach, Biogeosciences, 8, 853-873, doi:10.5194/bg-8-853-2011, 2011.

Lorenz, S. J. and Lohmann, G.: Acceleration technique for Milankovitch type forcing in a coupled atmosphere-ocean circulation model: method and application for the Holocene, Clim. Dynam., 23, 727-743, doi:10.1007/s00382-004-0469-y, 2004.

Lorenz, S. J., Kim, J.-H., Rimbu, N., Schneider, R. R., and Lohmann, G.: Orbitally driven insolation forcing on Holocene climate trends: Evidence from alkenone data and climate modeling, Paleoceanography, 21, PA1002, doi:10.1029/2005PA001152, 2006.

Lückge, A., Mohtadi, M., Rühlemann, C., Scheeder, G., Vink, A., Reinhardt, L., and Wiedicke, M.: Monsoon versus ocean circulation controls on paleoenvironmental conditions off southern Sumatra during the past 300,000 years, Paleoceanography, 24,
PA1208, doi:10.1029/2008PA001627, 2009.

Marchal, O., Cacho, I., Stocker, T. F., Grimalt, J. O., Calvo, E., Martrat, B., Shackleton, N., Vautravers, M., Cortijo, E., van Kreveld, S., Andersson, C., Koç, N., Chapman, M., Sbaffi, L., Duplessy, J.-C., Sarnthein, M., Turon, J.-L., Duprat, J., and Jansen, E.: Apparent long-term cooling of the sea surface in the Northeast Atlantic and Mediterranean during the Holocene, Quaternary Sci. Rev., 21, 455-483, 2002.

Marr, J. P., Baker, J. A., Carter, L., Allan, A. S. R., Dumbar, G. B., and Bostock, H. C.: Ecological and temperature controls on $\mathrm{Mg} / \mathrm{Ca}$ ratios of Globigerina bulloides from the southwest Pacific Ocean, Paleoceanography, 26, PA2209, doi:10.1029/2010PA002059, 2011.

Martrat, B., Grimalt, J. O., Lopez-Martinez, C., Cacho, I., Sierro, F. J., Flores, J. A., Zahn, R., Canals, M., Curtis, J. H., and Hodell, D. A.: Abrupt Temperature Changes in the Western Mediterranean over the Past 250,000 Years, Science, 306, 1762-1765, 2004.

Martrat, B., Grimalt, J. O., Shackleton, N. J., de Abreu, L., Hutterli, M. A., and Stocker, T. F.: Four climate cycles of recurring deep and surface water destabilizations on the Iberian Margin, Science, 27, 502-507, 2007.

Masson, V., Cheddadi, R., Braconnot, P., Joussaume, S., Texier, D., and PMIP participants: Mid-Holocene climate in Europe: what can we infer from PMIP model-data comparisons?, Clim. Dynam., 15, 163-182, 1999.

Masson-Delmotte, V., Kageyama, M., Braconnot, P., Charbit, S., Krinner, G., Ritz, C., Guilyardi, E., Jouzel, J., Abe-Ouchi, A., Crucifix, M., Gladstone, R. M., Hewitt, C. D., Kitoh, A., LeGrande, A. N., Marti, O., Merkel, U., Motoi, T., Ohgaito, R., Otto-Bliesner, B., Peltier, W. R., Ross, I., Valdes, P. J., Vettoretti, G., Weber, S. L., Wolk, F., and Yu, Y.: Past and future polar amplification of climate change: Climate model intercomparisons and ice-core constraints, Clim. Dynam., 26, 513-529, doi:10.1007/s00382-005-0081-9, 2006.

Mix, A. C.: The oxygen-isotope record of glaciation, in: North America and adjacent oceans during the last deglaciation, The Geology of North America, K-3, edited by: Ruddiman, W. F. and Wright, H. E., Geol. Soc. Am., Boulder CO, 111-135, 1987.

Mix, A. C., Bard, E., Eglinton, G., Keigwin, L. D., Ravelo, A. C., and Rosenthal, Y.: Alkenones and multiproxy strategies in paleoceanographic studies, Geochem. Geophy. Geosy., 1, 1033, doi:10.1029/2000GC000056, 2000.

Mohtadi, M., Steinke, S., Groeneveld, J., Fink, H. G., Rixen, T., Hebbeln, D., Donner, B., and Herunadi, B.: Low-latitude control on seasonal and interannual changes in planktonic foraminiferal flux and shell geochemistry off south Java: a sediment trap study, Paleoceanography, 24, PA1201, doi:10.1029/2008PA001636, 2009.

Moros, M., Emeis, K., Risebrobakken, B., Snowball, I., Kuijpers, A., McManus, J., and Jansen, E.: Sea surface temperatures and ice rafting in the Holocene North Atlantic: climate influences on northern Europe and Greenland, Quaternary Sci. Rev., 23, 21132126, 2004.

Mudelsee, M.: Climate Time Series Analysis: Classical Statistical and Bootstrap Methods, Springer, Dordrecht, Heidelberg, London, New York, 2010.

Müller, P. J. and Fischer, G.: A 4-year sediment trap record of alkenones from the filamentous upwelling region off Cape Blanc, NW Africa and a comparison with distributions in underlying 
sediments, Deep-Sea Res. Pt. I, 48, 1877-1903, 2001.

Müller, P. J., Kirst, G., Ruhland, G., von Storch, I., and RosellMelé, A.: Calibration of the alkenone paleotemperature index $U_{37}^{K^{\prime}}$ based on core-tops from the eastern South Atlantic and global ocean $\left(60^{\circ} \mathrm{N}-60^{\circ} \mathrm{S}\right)$, Geochim. Cosmochim. Acta, 62, 1757-1772, 1998.

Munk, W. H. and Riley, G. A.: Absorption of nutrients by aquatic plants, J. Mar. Res., 11, 215-240, 1952.

Nürnberg, D., Bijma, J., and Hemleben, C.: Assessing the reliability of magnesium in foraminiferal calcite as a proxy for water mass temperature, Geochim. Cosmochim. Acta, 60, 803-814, 1996.

Nürnberg, D., Ziegler, M., Karas, C., Tiedemann, R., and Schmidt, M. W.: Interacting loop current variability and Mississippi River discharge over the past $400 \mathrm{kyr}$, Earth Planet. Sc. Lett., 272, 278289, 2008.

Ohkouchi, N., Kawamura, K., Kawahata, H., and Okada, H.: Depth ranges of alkenone production in the central Pacific Ocean, Global Biogeochem. Cy., 13, 695-704, 1999.

Ohkouchi, N., Eglinton, T. I., Keigwin, L. D., and Hayes, J. M.: Spatial and temporal offsets between proxy records in a sediment drift, Science, 298, 1224-1227, doi:10.1126/science.1075287, 2002.

O'ishi, R. and Abe-Ouchi, A.: Polar amplification in the mid-Holocene derived from dynamical vegetation change with a GCM, Geophys. Res. Lett., 38, L14702, doi:10.1029/2011GL048001, 2011.

Ostermann, D. R., Olafsson, J., Manganini, S., Curry, W. B., and Honjo, S.: A dramatic increase in particle flux in the Iceland Sea since 1997, results from a 15-year time series, in: 7th International Conference on Paleoceanography, Program and Abstracts, Hokkaido University, Sapporo, Japan, p. 169, 2001.

Ostertag-Henning, C. and Stax, R.: Data report: Carbonate records from sites 1012, 1013, 1017, and 1019 and alkenone-based seasurface temperatures from site 1017, Proc. Ocean Drill. Program, Sci. Results, 167, 297-302, 2000.

Otto-Bliesner, B. L., Brady, E. C., Clauzet, G., Tomas, R., Levis, S., and Kothavala, Z.: Last Glacial Maximum and Holocene climate in CCSM3, J. Climate, 19, 2526-2544, 2006.

Pahnke, K., Sachs, J. P., Keigwin, L., Timmermann, A., and Xie, S.-P.: Eastern tropical Pacific hydrologic changes during the past 27,000 years from D/H ratios in alkenones, Paleoceanography, 22, PA4214, doi:10.1029/2007PA001468, 2007.

Pailler, D. and Bard, E.: High frequency paleoceanographic changes during the past 140,000 ears recorded by the organic matter in sediments off the Iberian Margin, Palaeogeogr. Palaeocl., 181, 431-452, 2002.

Park, W. and Latif, M.: Multidecadal and multicentennial variability of the meridional overturning circulation, Geophys. Res. Lett., 35, L22703, doi:10.1029/2008GL035779, 2008.

Park, W., Keenlyside, N., Latif, M. Ströh, A., Redler, R., Roeckner, E., and Madec, G.: Tropical Pacific climate and its response to global warming in the Kiel Climate Model, J. Climate, 22, 7192, 2009.

Pelejero, C., Grimalt, J. O., Heilig, S., Kienast, M., and Wang, L.: High-resolution $U_{37}^{K}$ temperature reconstructions in the South China Sea over the past $220 \mathrm{kyr}$, Paleoceanography, 14, 224-231, 1999a.
Pena, L. D., Cacho, I., Ferretti, P., and Hall, M. A.: El NiñoSouthern Oscillation-like variability during glacial terminations and interlatitudinal teleconnections, Paleoceanography, 23, PA3101, doi:10.1029/2008PA001620, 2008.

Peterson, L. C., Haug, G. H., Murray, R. W., Yarincik, K. M., King, J. W., Bralower, T. J., Kameo, K., Rutherford, S. D., and Pearce, R. B.: Late Quaternary stratigraphy and sedimentation at site 1002, Cariaco basin (Venezuela), Ocean Drill. Program, Sci. Results, 165, 85-99, 2000.

Phipps, S. J., Rotstayn, L. D., Gordon, H. B., Roberts, J. L., Hirst, A. C., and Budd, W. F.: The CSIRO Mk3L climate system model version 1.0 - Part 1: Description and evaluation, Geosci. Model Dev., 4, 483-509, doi:10.5194/gmd-4-483-2011, 2011.

Phipps, S. J., Rotstayn, L. D., Gordon, H. B., Roberts, J. L., Hirst, A. C., and Budd, W. F.: The CSIRO Mk3L climate system model version 1.0 - Part 2: Response to external forcings, Geosci. Model Dev., 5, 649-682, doi:10.5194/gmd-5-649-2012, 2012.

Prahl, F. G. and Wakeham, S. G.: Calibration of unsaturation patterns in long-chain ketone compositions for paleotemperature assessment, Nature, 330, 367-369, 1987.

Prahl, F. G., Muehlhausen, L. A., and Zahnle, D. L.: Further evaluation of long-chain alkenones as indicators of paleoceanographic conditions, Geochim. Cosmochim. Acta, 52, 2303-2310, 1988.

Prahl, F. G., Rontani, J.-F., Zabeti, N., Walinsky, S. E., and Sparrow, M. A.: Systematic pattern in $U_{37}^{K^{\prime}}$ Temperature residuals for surface sediments from high latitude and other oceanographic settings, Geochim. Cosmochim. Acta, 74, 131-143, doi:10.1016/j.gca.2009.09.027, 2010.

Raddatz, T. J., Reick, C. H., Knorr, W., Kattge, J., Roeckner, E., Schnur, R., Schnitzler, K.-G., Wetzel, P., and Jungclaus, J.: Will the tropical land biosphere dominate the climate-carbon cycle feedback during the twentyfirst century?, Clim. Dynam., 29, 565-574, doi:10.1007/s00382-007-0247-8, 2007.

Regenberg, M., Nürnberg, D., Steph, S., Groeneveld, J., GarbeSchönberg, D., Tiedemann, R., and Dullo, W.-C.: Assessing the effect of dissolution on planktonic foraminiferal $\mathrm{Mg} / \mathrm{Ca}$ ratios: Evidence from Caribbean core tops, Geochem. Geophy. Geosy., 7, Q07P15, doi:10.1029/2005GC001019, 2006.

Regenberg, M., Steph, S., Nürnberg, D., Tiedemann, R., and GarbeSchönberg, D.: Calibrating $\mathrm{Mg} / \mathrm{Ca}$ ratios of multiple planktonic foraminiferal species with $\delta^{18} \mathrm{O}$ calcification temperatures: $\mathrm{Pa}-$ leothermometry for the upper water column, Earth Planet. Sc. Lett., 278, 324-336, doi:10.1016/j.eps1.2008.12.019, 2009.

Renssen, H., Goosse, H., Fichefet, T., Brovkin, V., Driesschaert, E., and Wolk, F.: Simulating the Holocene climate evolution at northern high latitudes using a coupled atmosphere-sea iceocean-vegetation model, Clim. Dynam., 24, 23-43, 2005.

Rimbu, N., Lohmann, G., Kim, J.-H., Arz, H. W., and Schneider, R. R.: Arctic/North Atlantic Oscillation signature in Holocene sea surface temperature trends as obtained from alkenone data, Geophys. Res. Lett., 30, 1280, doi:10.1029/2002GL016570, 2003.

Rimbu, N., Lohmann, G., Lorenz, S. J., Kim, J.-H., and Schneider, R. R.: Holocene climate variability as derived from alkenone sea surface temperature and coupled ocean-atmosphere model experiments, Clim. Dynam., 23, 215-227, doi:10.1007/s00382004-0435-8, 2004. 
Rodrigues, T., Grimalt, J. O., Abrantes, F. G., Flores, J. A., and Lebreiro, S. M.: Holocene interdependences of changes in sea surface temperature, productivity, and fluvial inputs in the Iberian continental shelf (Tagus mud patch), Geochem. Geophy. Geosy., 10, Q07U06, doi:10.1029/2008GC002367, 2009.

Roeckner, E., Arpe, K., Bengtsson, L., Christoph, M., Claussen, M., Dümenil, L., Esch, M., Giorgetta, M., Schlese, U., and Schulzweida, U.: The atmospheric general circulation model ECHAM-4: model description and simulation of the present day climate, Report 218, Max-Planck-Institut für Meteorologie, Hamburg, 1996.

Roeckner, E., Bäuml, G., Bonaventura, L., Brokopf, R., Esch, M., Giorgetta, M., Hagemann, S., Kirchner, I., Kornblueh, L., Manzini, E., Rhodin, A., Schlese, U., Schulzweida, U., and Tompkins, A.: The atmospheric general circulation model ECHAM5, PART I: Model description, Report 349, Max-Planck-Institut für Meteorologie, Hamburg, 2003.

Rohling, E. J., Medina-Elizalde, M., Shepherd, J. G., Siddall, M., and Stanford, J. D.: Sea surface and high-latitude temperature sensitivity to radiative forcing of climate over several glacial cycles, J. Climate, 25, 1635-1656, 2012.

Romero, O. E., Kim, J.-H., and Donner, B.: Submillennial-tomillennial variability of diatom production off Mauritania, NW Africa, during the last glacial cycle, Paleoceanography, 23, PA3218, doi:10.1029/2008PA001601, 2008.

Rosell-Melé, A., Eglinton, G., Pflaumann, U., and Sarnthein, M.: Atlantic core-top calibration of the $U_{37}^{K^{\prime}}$ index as sea-surface palaeotemperature indicator, Geochim. Cosmochim. Acta, 59, 3099-3107, 1995.

Rosenthal, Y., Perron-Cashman, S., Lear, C. H., Bard, E., Barker, S., Billups, K., Bryan, M., Delaney, M. L., deMenocal, P. B., Dwyer, G. S., Elderfield, H., German, C. R., Greaves, M., Lea, D. W., Marchitto Jr., T. M., Pak, D. K., Paradis, G. L., Russell, A. D., Schneider, R. R., Scheiderich, K., Stott, L., Tachikawa, K., Tappa, E., Thunell, R., Wara, M., Weldeab, S., and Wilson, P. A.: Interlaboratory comparison study of $\mathrm{Mg} / \mathrm{Ca}$ and $\mathrm{Sr} / \mathrm{Ca}$ measurements in planktonic foraminifera for paleoceanographic research, Geochem. Geophy. Geosy., 5, Q04D09, doi:10.1029/2003GC000650, 2004.

Rühlemann, C. and Butzin, M.: Alkenone temperature anomalies in the Brazil-Malvinas Confluence area caused by lateral advection of suspended particulate material, Geochem. Geophy. Geosy., 7, Q10015, doi:10.1029/2006GC001251, 2006.

Rühlemann, C., Mulitza, S., Müller, P. J., Wefer, G., and Zahn, R.: Warming of the tropical Atlantic Ocean and slowdown of thermohaline circulation during the last deglaciation, Nature, 402, 511-514, 1999.

Russell, G. L., Miller, J. R., and Rind, D. H.: A coupled atmosphereocean model for transient climate change, Atmos. Ocean, 33, 683-730, 1995.

Sachs, J. P.: Cooling of Northwest Atlantic slope waters during the Holocene, Geophys. Res. Lett., 34, L03609, doi:10.1029/2006GL028495, 2007.

Sarnthein, M., van Kreveld, S., Erlenkeuser, H., Grootes, P. M., Kucera, M., Pflaumann, U., and Schulz, M.: Centennial-tomillennial-scale periodicities of Holocene climate and sediment injections off the western Barents shelf, $75^{\circ} \mathrm{N}$, Boreas, 32, 447$461,2003$.
Sawada, K. and Handa, N.: Variability of the path of the Kuroshio ocean current over the past 25,000 years, Nature, 392, 592-595, 1998.

Schefuß, E., Schouten, S., and Schneider, R. R.: Climatic controls on central African hydrology during the last 20,000 years, Nature, 437, 1003-1006, 2005.

Schiebel, R., Bijma, J., and Hemleben, Ch.: Population dynamics of the planktic foraminifer Globigerina bulloides from the eastern North Atlantic (JGOFS), Deep-Sea Res. Pt. II, 44, 1701-1713, 1997.

Schmidt, G. A.: Enhancing the relevance of palaeoclimate model/data comparisons for assessments of future climate change, J. Quaternary Sci., 25, 79-87, 2010.

Schmidt, G. A., Ruedy, R., Hansen, J. E., Aleinov, I., Bell, N., Bauer, M., Bauer, S., Cairns, B., Canuto, V., Cheng, Y., Genio, A. D., Faluvegi, G., Friend, A. D., Hall, T. M., Hu, Y., Kelley, M., Kiang, N. Y., Koch, D., Lacis, A. A., Lerner, J., Lo, K. K., Miller, R. L., Nazarenko, L., Oinas, V., Perlwitz, J., Perlwitz, J., Rind, D., Romanou, A., Russell, G. L., Sato, M., Shindell, D. T., Stone, P. H., Sun, S., Tausnev, N., Thresher, D., and Yao, M. S.: Present-day atmospheric simulations using GISS ModelE: comparison to in situ, satellite, and reanalysis data, J. Climate, 19, 153-192, 2006.

Schneider, B., Leduc, G., and Park, W.: Disentangling seasonal signals in Holocene climate trends by satellitemodel-proxy integration, Paleoceanography, 25, PA4217, doi:10.1029/2009PA001893, 2010.

Schneider, R. R., Müller, P. J., Ruhland, G., Meinecke, G., Schmidt, H., and Wefer, G.: Late Quarternary surface temperatures and productivity in the east-equatorial South Atlantic: response to changes in trade/monsoon wind forcing and surface water advection, in: The South Atlantic: Present and Past Circulation, edited by: Wefer, G., Berger, W. H., Siedler, G., and Webb, D., Springer, Berlin, Heidelberg, 527-551, 1996.

Scholz, P., Lohmann, G., Wang, Q., and Danilov, S.: Validation of a Finite-Element Sea-Ice ocean model (FESOM) setup to study the interannual to decadal variability in the deep-water formation rates, Ocean Dynam., 63, 347-370, doi:10.1007/s10236012-0590-0, 2013.

Schulz, H., Emeis, K.-C., Erlenkeuser, H., von Rad, U., and Rolf, C.: The Toba Volcanic Event and interstadial/stadial climates at the marine isotopic stage 5 to 4 transition in the Northern Indian Ocean, Quatern. Res., 57, 22-31, 2002.

Seki, O., Ikehara, M., Kawamura, K., Nakatsuka, T., Ohnishi, K., Wakatsuchi, M., Narita, H., and Sakamoto, T.: Reconstruction of paleoproductivity in the Sea of Okhotsk over the last $30 \mathrm{kyr}, \mathrm{Pa}-$ leoceanography, 19, PA1016, doi:10.1029/2002PA000808, 2004.

Sicre, M.-A., Labeyrie, L., Ezat, U., Duprat, J., Turon, J.-L., Schmidt, S., Michel, E., and Mazaud, A.: Mid-latitude Southern Indian Ocean response to Northern Hemisphere Heinrich events, Earth Planet. Sc. Lett., 240, 724-731, 2005.

Sikes, E. L., Volkman, J. K., Robertson, L. G., and Pichon, J.-J.: Alkenones and alkenes in surface waters and sediments of the Southern Ocean: Implications for paleotemperature estimation in polar regions, Geochim. Cosmochim. Acta, 61, 1495-1505, 1997. 
Sikes, E. L., Howard, W. R., Neil, H. L., and Volkman, J. K.: Glacial-interglacial sea surface temperature changes across the subtropical front east of New Zealand based on alkenone unsaturation ratios and foraminiferal assemblages, Paleoceanography, 17, 1012, doi:10.1029/2001PA000640, 2002.

Sonzogni, C., Bard, E., Rostek, F., Dollfus, D., Rosell-Melé, A., and Eglinton, G.: Temperature and salinity effects on alkenones ratios measured in sediments from the Indian Ocean, Quatern. Res., 47, 344-355, 1997.

Sperling, M., Schmiedl, G., Hemleben, C., Emeis, K.-C., Erlenkeuser, H., and Grootes, P.: Black Sea impact on the formation of eastern Mediterranean sapropel S1: evidence from the Marmara Sea, Palaeogeogr. Palaeocl., 190, 9-21, 2003.

Steinke, S., Kienast, M., Groeneveld, J., Lin, L.-C., Chen, M.-T., and Rendle-Bühring, R.: Proxy dependence of the temporal pattern of deglacial warming in the tropical South China Sea: toward resolving seasonality, Quaternary Sci. Rev., 27, 688-700, 2008.

Stott, L. D., Cannariato, K., Thunell, R., Haug, G., Koutavas, A., and Lund, S.: Decline of western tropical pacific surface ocean temperatures and salinities in the Holocene, Nature, 431, 56-59, 2004.

Sun, Y., Oppo, D. W., Xiang, R., Liu, W., and Gao, S.: The last deglaciation in the Okinawa Trough: subtropical northwest Pacific link to northern and tropical climate, Paleoceangraphy, 20, PA4005, doi:10.1029/2004PA001061, 2005.

Sundqvist, H. S., Zhang, Q., Moberg, A., Holmgren, K., Körnich, H., Nilsson, J., and Brattström, G.: Climate change between the mid and late Holocene in northern high latitudes - Part 1: Survey of temperature and precipitation proxy data, Clim. Past, 6, 591608, doi:10.5194/cp-6-591-2010, 2010.

Tachikawa, K., Sépulcre, S., and Toyofuku, T.: Assessing influence of diagenetic carbonate dissolution on planktonic foraminiferal $\mathrm{Mg} / \mathrm{Ca}$ in the southeastern Arabian Sea over the past $450 \mathrm{ka}$ : Comparison between Globigerinoides ruber and Globigerinoides sacculifer, Geochem. Geophy. Geosy., 9, Q04037, doi:10.1029/2007GC001904, 2008.

Taylor, K. E., Stouffer, R. J., and Meehl, G. A.: An Overview of CMIP5 and the experiment design, B. Am. Meteorol. Soc., 93, 485-498, doi:10.1175/BAMS-D-11-00094.1, 2012.

Ternois, Y., Sicre, M.-A., Boireau, A., Conte, M. H., and Eglinton, G.: Evaluation of long-chain alkenones as paleo-temperature indicators in the Mediterranean Sea, Deep-Sea Res. Pt. I, 44, 271286, 1997.

Thornalley, D. J. R., Elderfield, H., and McCave, N.: Holocene oscillations in temperature and salinity of the surface subpolar North Atlantic, Nature, 457, 711-714, 2009.

Thunell, R. C., Curry, W. B., and Honjo, S.: Seasonal variation in the flux of planktonic foraminifera: time series sediment trap results from the Panama Basin, Earth Planet. Sc. Lett., 64, 44-55, 1983.

Vinther, B., Buchardt, S. L., Clausen, H. B., Dahl-Jensen, D., Johnsen, S. J., Fisher, D. A., Koerner, R. M., Raynaud, D., Lipenkov, V, Andersen, K. K., Blunier, T., Rasmussen, S. O., Steffensen, J. P., and Svensson, A. M.: Holocene thinning of the Greenland ice sheet, Nature, 461, 385-388, doi:10.1038/nature08355, 2009.

Visser, K., Thunell, R., and Stott, L.: Magnitude and timing of temperature change in the Indo-Pacific warm pool during deglaciation, Nature, 421, 152-155, 2003.
Voldoire, A., Sanchez-Gomez, E., Salas y Mélia, D., Decharme, B., Cassou, C., Sénési, S., Valcke, S., Beau, I., Alias, A., Chevallier, M., Déqué, M., Deshayes, J., Douville, H., Fernandez, E., Madec, G., Maisonnave, E., Moine, M. P., Planton, S., SaintMartin, D., Szopa, S., Tyteca, S., Alkama, R., Belamari, S., Braun, A., Coquart, L., and Chauvin, F.: The CNRMCM5.1 global climate model: description and basic evaluation, Clim. Dynam., 40, 2091-2121, doi:10.1007/s00382-011-1259-y, 2012. von Storch, H. and Zwiers, F. W.: Statistical Analysis in Climate Research, Cambridge Univ. Press, New York, 1999.

Wang, L., Sarnthein, M., Duplessy, J.-C., Erlenkeuser, H., Jung, S., and Pflaumann, U.: Paleoseasurface salinities in the low-latitude Atlantic, The $\delta^{18} \mathrm{O}$ record of Globigerinoides ruber (white), $\mathrm{Pa}$ leoceanography, 10, 749-761, 1995.

Wang, L., Sarnthein, M., Erlenkeuser, H., Heilig, S., Ivanova, E., Kienast, M., Pflaumann, U., Pelejero, C., and Grootes, P.: East Asian monsoon during the late Quaternary: high-resolution sediment records from the South China Sea, Mar. Geol., 156, 245284, 1999.

Wei, W. and Lohmann, G.: Simulated Atlantic Multidecadal Oscillation during the Holocene, J. Climate, 25, 6989-7002, doi:10.1175/JCLI-D-11-00667.1, 2012.

Weldeab, S., Schneider, R. R., and Kölling, M.: Deglacial sea surface temperature and salinity increase in the western tropical Atlantic in synchrony with high latitude climate instabilities, Earth Planet. Sc. Lett., 241, 699-706, 2006.

Weldeab, S., Schneider, R. R., and Mueller, P.: Comparison of $\mathrm{Mg} / \mathrm{Ca}$ and alkenone based sea surface temperature reconstructions in the fresh water influenced eastern equatorial Atlantic during the last 21,000 years, Geochem. Geophy. Geosy., 8, doi:10.1029/2006GC001360, 2007a.

Weldeab, S., Lea, D. W., Schneider, R. R., and Andersen, N.: 155,000 years of West African monsoon and ocean thermal evolution, Science, 316, 1303-1307, $2007 \mathrm{~b}$.

Wirtz, K. W., Lohmann, G., Bernhardt, K., and Lemmen, C.: Mid-Holocene regional reorganization of climate variability: Analyses of proxy data in the frequency domain, Palaeogeogr. Palaeoecol., 298, 189-200, doi:10.1016/j.palaeo.2010.09.019, 2010.

Wolff, J.-O., Maier-Reimer, E., and Legutke, S.: The Hamburg ocean primitive equation model HOPE, technical report 13, Deutsches Klimarechenzentrum, Hamburg, 1997.

Wu, T., Li, W., Ji, J., Xin, X., Li, L., Wang, Z., Zhang, Y., Li, J., Zhang, F., Wei, M., Shi, X., Wu, F., Zhang, L., Chu, M., Jie, W., Liu, Y., Wang, F., Liu, X., Li, Q., Dong, M., Liu, Q., and Zhang, J.: Global carbon budgets simulated by the Beijing Climate Center Climate System Model for the last century, J. Geophys. Res.Atmos., 118, 4326-4347, doi:10.1002/jgrd.50320, 2013.

Xu, J., Holbourn, A., Kuhnt, W., Jian, Z., and Kawamura, H.: Changes in the thermocline structure of the Indonesian outflow during Terminations I and II, Earth Planet. Sc. Lett., 273, 152$162,2008$.

Yu, Y. Q., Yu, R. C., Zhang, X. H., and Liu, H. L.: A flexible coupled ocean-atmosphere general circulation model, Adv. Atmos. Sci., 19, 169-190, 2002.

Yu, Y. Q., Zhang, X. H., and Guo, Y. F.: Global coupled oceanatmosphere general circulation models in LASG/IAP, Adv. Atmos. Sci., 21, 444-455, 2004. 
Yukimoto, S., Noda, A., Kitoh, A., Hosaka, M., Yoshimura, H., Uchiyama, T., Shibata, K., Arakawa, O., and Kusunoki, S.: Present-day climate and climate sensitivity in the Meteorological Research Institute coupled GCM version 2.3 (MRI-CGCM2.3), J. Meteorol. Soc. Japan, 84, 333-363, 2006.

Yukimoto, S., Adachi, Y., Hosaka, M., Sakami, T., Yoshimura, H., Hirabara, M., Tanaka, T. Y., Shindo, E., Tsujino, H., Deushi, M., Mizuta, R., Yabu, S., Obata, A., Nakano, H., Ose, T., and Kitoh, A.: A new global climate model of Meteorological Research Institute: MRI-CGCM3 - Model description and basic performance, J. Meteorol. Soc. Jpn., 90a, 23-64, 2012.
Zhang, Q., Sundqvist, H. S., Moberg, A., Körnich, H., Nilsson, J., and Holmgren, K.: Climate change between the mid and late Holocene in northern high latitudes - Part 2: Model-data comparisons, Clim. Past, 6, 609-626, doi:10.5194/cp-6-609-2010, 2010.

Zhao, M., Beveridge, N. A. S., Shackleton, N. J., Sarnthein, M., and Eglinton, G.: Molecular stratigraphy of cores off northwest Africa: Sea surface temperature history over the last $80 \mathrm{ka}$, Paleoceanography, 10, 661-675, 1995.

Zhao, M., Huang, C.-Y., Wang, C.-C., and Wei, G.: A millennialscale $U_{37}^{K^{\prime}}$ sea surface temperature record from the South China Sea $\left(8^{\circ} \mathrm{N}\right)$ over the last $150 \mathrm{kyr}$ : Monsoon and sea level influence, Palaeogeography, Palaeoclimatology, Palaeoecology, 36, 39-55, 2006. 